\title{
A comprehensive systematic review of the impact of planned interventions offered to pregnant women who have requested a caesarean section as a result of tokophobia (fear of childbirth)-
}

Jane Weaver ${ }^{1}$ PGDip, CPsychol, PhD, BSc, RM, RGN, JBI Collaborating Centre, College of Nursing, Midwifery and Healthcare, University of West London, London, UK.

Jessica Browne ${ }^{2} \mathrm{MPH}$, BA (Hons), JBI Collaborating Centre, College of Nursing, Midwifery and Healthcare, University of West London, London, UK.

Andrea Aras-Payne ${ }^{3}$ PGDip, MA, RM, RGN, Bsc (Hons), JBI Collaborating Centre, College of Nursing, Midwifery and Healthcare, University of West London, London, UK.

Julia Magill-Cuerden ${ }^{4}$ PhD, MA, Dip Ed Man, Dip Nursing, MTD, RM, RN, JBI Collaborating Centre, College of Nursing, Midwifery and Healthcare, University of West London, London, UK.

Contact Details: Address: Paragon House Boston Manor Road Brentford, Middlesex TW8 9GB; Tel: +44 (0)20 8209 4105; E-mail: jane.weaver@uwl.ac.uk.

\section{Executive Summary}

\section{Background}

Tokophobia, a deep-seated fear of childbirth, causes women emotional anguish and affects the motherbaby relationship. It can result in women avoiding future pregnancies or requesting caesarean section. This review examines evidence for the effectiveness of planned interventions in women with tokophobia in both reducing requests for caesarean section and in ameliorating maternal distress.

\section{Objectives}

1) To synthesise the best available quantitative evidence for the effectiveness of planned interventions in reducing: a) fear/anxiety in tokophobic women, b) planned caesarean sections

2) To synthesise the best available qualitative evidence relating to the experiences of tokophobic women who request a caesarean section, particularly satisfaction with interventions and the childbirth experience.

\section{Inclusion criteria}

This review considered studies that included pregnant women requesting a caesarean section for tokophobia in the absence of medical (or obstetric) indications who were offered a planned intervention.

\section{Search strategy}

The literature search focused on published and unpublished studies in English distributed between January 1990 and April 2012. An initial limited database search was undertaken to identify keywords, followed by an extensive search of relevant databases and potential grey material. 


\section{Methodological quality}

Assessment for methodological quality was carried out independently by two reviewers using the standardised appraisal tools from the Joanna Briggs Institute.

\section{Data extraction}

Data were extracted from papers included in the review using the standardised data extraction tool from the Joanna Briggs Institute.

\section{Data synthesis}

Statistical meta-analysis was not possible due to heterogeneity. Therefore, a narrative summary of the data was undertaken.

\section{Results}

Nine quantitative papers (comprising eight studies: one randomised controlled trial, five case control studies and two descriptive case series) were included; two of these papers appertained to the same study. No qualitative papers were found.

Definitions for tokophobia varied. Samples were confounded by the inclusion of women with complex obstetric histories or with mental health issues. Comparison groups were sometimes non-tokophobic women. Interventions were complex and descriptions sometimes lacked clarity. Although the randomised controlled trial found no difference in birth choices between samples, a group therapy intervention predisposed women to vaginal birth. One study measured whether interventions reduced fear, finding that they did. Four studies explored satisfaction with the intervention. In three cases interventions were evaluated positively. These involved midwifery input and birth planning.

\section{Conclusion}

More research is needed to identify how tokophobic women might be helped. Current guidelines should be upheld for the time being, in the absence of further evidence.

\section{Implications for practice}

Due to the heterogeneous nature of the research it is impossible at this stage to draw conclusions for practice.

\section{Implications for research}

Due to ethical concerns about randomising tokophobic women to non-treatment groups, innovative research designs should be considered.

More research is needed on the effectiveness of group interventions and the role of midwives in administering interventions.

A standard, measurable definition for tokophobia is needed and careful documentation and differential analysis of women's parity, mental health and obstetric status should be made.

Outcomes should include fear reduction. Satisfaction and birth outcome should be measured on more than one occasion. 
Key words: Tokophobia; tocophobia; parturiphobia; maieusiophobia; fear of childbirth; childbirth related anxiety; counselling; CBT; cognitive behavioural therapy; cognitive therapy; caesarean section; caesarean delivery; abdominal delivery. 


\section{Background}

Tokophobia (from the Greek 'tokos', meaning childbirth and 'phobos', meaning fear) has been defined as "dread and avoid[ance] of childbirth despite desperately wanting a baby" and has been described as a specific and harrowing condition that needs acknowledging. ${ }^{1}$ Tokophobia is also sometimes known as 'tocophobia', 'parturiphobia' or 'maieusiophobia'.

The number of childbearing women experiencing these heightened levels of fear and anxiety is unclear. However, recent research has indicated that it is not the rare condition it was originally considered to be. Laursen et al. ${ }^{2}$ found that fear of childbirth (FOC) was reported by $7.6 \%$ women in early pregnancy and $7.4 \%$ in late pregnancy, with $3.2 \%$ of the women expressing FOC in both. However, others have estimated that, while $80 \%$ of low risk pregnant women describe common childbirth anxieties, ${ }^{3}$ intense fear is expressed by over $20 \%$ of pregnant women ${ }^{4}$ with $6-10 \%$ reporting pathological levels of fear. ${ }^{3}$ Nevertheless, these figures do not take into account those women who choose not to become pregnant because of their phobia.

In tandem with the growing acknowledgement of tokophobia has been an increasing concern, in developed countries, over the rising caesarian section (CS) rate. In the UK, the rate has risen from around $3 \%$ in the $1960 \mathrm{~s}^{5}$ to $24.8 \%$ in $2009-10 .{ }^{6}$ - This is considerably higher than the maximum medically justified rate of $15 \%$, as defined by the World Health Organization (WHO). ${ }^{7}$-A number of authorities have expressed concern at this trend, ${ }^{8}$ as surgical intervention in childbirth may result in adverse maternal or infant outcomes. ${ }^{9,10}$-For example, a higher proportion of infants delivered by CS have been reported to suffer from respiratory distress compared to those delivered vaginally; ${ }^{11,12} \mathrm{CS}$ may interfere with breast feeding, due to differing levels of oxytocin and prolactin between mothers delivering abdominally and vaginally; ${ }^{13}$ and severe maternal morbidity has been shown to be threefold higher in connection with CS compared to vaginal birth. ${ }^{14}$ In addition, in all healthcare systems, the financial cost of a CS is about twice that of a vaginal delivery. ${ }^{15}$

There has been much debate over the reasons for the great increase in CS rates. Around the turn of the century, particular concerns started to be raised over anecdotal and limited research evidence that suggested there were growing numbers of women requesting delivery by $C S$ in the absence of any clinical indications. ${ }^{16}$-Alongside this, there developed -growing media rhetoric around women who were 'too posh to push'. ${ }^{17}$-There has been a tendency to vilify such women in the popular press and to hold them responsible for the rising CS rate.

In an effort to determine what was causing the CS rate to rise, and to provide accurate data (all previously cited CS rates had been estimated or extrapolated), in 2001 the UK Department of Health commissioned The National Sentinel Caesarean Section Audit. ${ }^{18}$ This consisted of data from a threemonth long audit of all CS performed in England, Wales and Northern Ireland in 2000. The audit found that the main reasons for carrying out a CS were clinical. However, maternal request (in the absence of clinical indication) was also a primary factor, accounting for $7.3 \%$ of all CS. Although the accuracy of this data was disputed due to the nature of its collection, ${ }^{19}$ the audit was able to confirm that significant 
numbers of women were asking for their babies to be delivered operatively. Unfortunately, however, the reasons behind these requests were outside the scope of the audit.

Nevertheless, work in Scandinavia had already established the fact that FOC (albeit not labelled tokophobia) was associated with maternal request for $\mathrm{CS}^{20,21}$ and increasingly studies in the UK and elsewhere began to emerge suggesting that many women who requested $C S$ in the absence of clinical indication were, indeed, too frightened to go through with a vaginal birth. ${ }^{22-24}$-A study by Gamble and Creedy ${ }^{25}$ found a preference for CS in women who felt 'frightened' or 'nervous' about labour, or used the terms 'awful' or 'unpleasant' to describe birth. Nilstun et al. ${ }^{26}$ observed that many cases of CS for maternal request appear to be linked to particular personal circumstances including previous negative experiences and specific fears or anxiety for vaginal birth. One Finnish hospital calculated that $8 \%$ of all CS were carried out because of fear of vaginal delivery. ${ }^{21}$ - In a study of 43 sets of hospital case notes of women who underwent an elective CS for psychosocial indications, Ryding et al. ${ }^{27}$ found that their reasons were primarily a 'very serious fear of childbirth'.

The underlying factors and causes of tokophobia are not fully understood but appear to be complex. Laursen et al. ${ }^{2}$ notes that FOC in nulliparous women most often occurs among women with few social and psychological resources. Rouhe et al. ${ }^{28}$ found that mental health problems were twice as common among women with a FOC than in non-fearful controls.

The focus of tokophobic women's fears are also varied and complex, albeit somewhat better understood. They appear to centre around:

- fear of pain

- previous traumatic events (e.g. sexual abuse)

- personality factors

- psychosocial problems

- feelings of helplessness in anticipation of the childbirth process/event

- anxiety about parenthood

- lack of support

- low educational level

- the medicalisation of childbirth

- 'horror stories' from others and the media

- previous childbirth experiences (also known as secondary tokophobia). ${ }^{29-33}$

As identified above, secondary tokophobia may be as a result of a previous negative childbirth experience. In an Australian study of 20 women who had previously given birth by CS, McGrath and Ray-Barruel ${ }^{34}$ found that $80 \%$ of mothers chose elective CS for their subsequent birth. The reasons cited were fear and the desire to retain some control over the birthing process. In a study involving semi-structured interviews with six women who feared and avoided childbirth despite wanting another 
baby, Onley ${ }^{35}$ discussed feelings of violation of expectations, loss of control and 'loss of self' resulting from a previous birth.

The effects of tokophobia can be profound. It can cause emotional anguish to the woman and may impinge on the mother-baby relationship. However, as intimated above, it can also result in the woman taking steps to avoid labour, either by avoiding pregnancy altogether ${ }^{35}$-or, as discussed earlier, by requesting delivery by CS. Women with tokophobia have also been shown to have higher rates of hyperemesis gravidarum (a severe form of morning sickness), while some women have even been known to terminate a much wanted pregnancy because they could not face the prospect of giving birth. ${ }^{1-}$ Moreover, maternal anxiety and stress are found to be predictors of adverse pregnancy outcomes, including low birth weight and prematurity. ${ }^{36}$ It is argued that fear itself can have physiological effects that impede the progress of labour and thus increase the likelihood of obstetric intervention and ultimately delivery by CS, usually in this case, as an emergency procedure. ${ }^{37,38}$ However Johnson and Slade ${ }^{39}$ found that emergency CS was associated with previous CS, parity, age and a score reflecting medical risk, but not FOC or anxiety measures. Nevertheless, it should be noted that the response rate to questionnaires was low in this study $(35 \%)$ and the UK sample, regardless of mode of giving birth, showed greatly elevated levels of fear compared with Ryding et al.'s ${ }^{38}$ Swedish sample, perhaps suggesting that the findings were blunted by the overall high levels of anxiety in the women in this study sample. Onley ${ }^{35}$ found that some tokophobic women report symptoms of postnatal depression alongside post-traumatic stress.

As described earlier, much of the research around tokophobia has taken place in Scandinavian countries, where there has been a growing interest in the subject. As a result, recognition and treatment of childbirth fear has been established for some time in Scandinavia and there has been a growing trend to offer counselling to women requesting a CS due to tokophobia. ${ }^{40}$ However, there has been little evaluation of the effectiveness of these interventions. Moreover, it is evident that clear guidance focusing on how to best support women with tokophobia in other countries is required. In 2004, The National Institute for Clinical Excellence (NICE), the government-sponsored healthcare regulator for England and Wales, published its guidelines on CS, ${ }^{41}$ stating that:

"When a woman requests a caesarean section because she has a fear of childbirth, she should be offered counselling (such as cognitive behavioural therapy) to help her to address her fears in a supportive manner, because this results in reduced fear of pain in labour and shorter labour". ${ }^{41(p 38)}$

However, evidence for this recommendation was based on the findings of only one randomised controlled trial $(\mathrm{RCT}){ }^{21}$ in which women, referred to an antenatal clinic for FOC, were randomised to receive either cognitive therapy or usual care. No difference was detected between the groups in the proportion of women who chose to deliver by $\mathrm{CS}$, and the difference in pregnancy-related anxiety during therapy was not significant. However, fewer women in the intervention group reported fear of pain in labour and fear of obstetrician's unfriendly behaviour. These women also experienced shorter labours and the therapy did reduce birth-related concerns. Unfortunately, this study included only 176 participants and, of these, just $112(64 \%)$ completed all three questionnaires. Thus, evidence on which current guidelines are based is limited. Moreover, the guidelines recommend an intervention that has 
not been shown to be effective at reducing the number of CS requests. These concerns, combined with those surrounding the rising CS rate, indicate that it is important to explore whether there are effective psychological interventions that will not only ameliorate women's intense fear, but which will also give them the confidence to attempt vaginal birth.

Thus, while the current primary focus of counselling sessions for tokophobic women is to reduce fear and anxiety, ${ }^{41}$ movement towards a reduction in CS rates would also fit in with the current view and desire to decrease CS rates. ${ }^{42-44}$ Although a Cochrane review completed in 2006 found no evidence upon which to base any practice recommendations regarding planned CS for non-medical reasons at term, ${ }^{45}$ a number of potential interventions to address FOC do exist. However, the most effective type of intervention remains unclear. Cognitive behavioural therapy (CBT), as used as an exemplar by NICE, is a highly specific programme of therapy. ${ }^{46}$ Other forms of intervention cannot necessarily be considered to be comparable in terms of their effectiveness and must be explored separately for their potential therapeutic effects.

Findings have additionally suggested that women's requests and decision-making for birth intervention can be associated with fear relating to differences in the power-base between professional caregivers and women. ${ }^{47}$ Maternity caregivers have been identified as both a cause of this fear and a potential mediating factor in reducing it, demonstrating the importance to midwifery practice of understanding, recognising and addressing women's fears relating to childbirth. However, the exact nature of the form of training that midwives or other healthcare professionals should undertake to enhance these skills is not determined. Therefore, a question to be considered is: who is best placed to provide interventions for women with tokophobia?

An updated version of the NICE guidelines has recently been published. ${ }^{48}$ The new guidelines postulate that women requesting CS for FOC should be offered interventions such as CBT; support from a named member of the maternity team; carer continuity; and formal counselling. However, NICE observed that there was no clear evidence to suggest any specific interventions for providing care for women requesting a CS are of benefit. One prospective cohort study conducted in Sweden ${ }^{49}$ relating to maternal outcomes in women with FOC was discussed. The quality of this study was, however, considered to be 'very low'. As with the 2004 NICE guidelines, qualitative data was not used to inform this guidance. This lack of identification of further evidence for the effectiveness of interventions in women requesting CS suggests that, once again, the net is not being spread wide enough.

As is evident from the paucity of, and limited, research findings utilised by NICE, there is a need for a comprehensive review of the subject area. This may pave the way for further research in collaboration with practice partners in areas that have so far been neglected. The overall purpose of this review is to explore the effectiveness of supportive interventions applied in clinical practice for women who present requesting a CS due to tokophobia. It is hoped that this will result in a clearer understanding of the most effective forms of support, care and advice for women with an intense FOC, so as to reduce their levels of fear and anxiety, reduce the CS rate and adverse outcomes of interventions, and promote women's mental health and confidence in giving birth. 
Previous reviews have been carried out or proposed relating to: the factors influencing women's birthing preferences (protocol); ${ }^{50}$ information supplied to pregnant women about CS; ${ }^{51}$ debriefing for the prevention of psychological trauma in women following childbirth (protocol); ${ }^{52}$ psychosomatic approaches to obstetrics, gynaecology and andrology; ${ }^{53}$ and non-clinical interventions for reducing unnecessary CS. ${ }^{54}$ No systematic review to date has, however, explored the impact of planned interventions on pregnant women with tokophobia who have requested a CS.

\section{Review objectives}

The objectives of this review were to:

- synthesise the best available quantitative evidence relating to the effectiveness of planned interventions (intervention vs. standard care, or intervention vs. intervention) in reducing fear and/or anxiety in women who present with tokophobia, and in reducing the number of planned CS deliveries in these women, and

- synthesise the best available qualitative evidence relating to the experiences of women with tokophobia who request a CS, particularly in terms of satisfaction with planned interventions and the subsequent childbirth experience.

More specifically, the review questions were:

-What planned interventions are offered to women requesting a CS due to tokophobia (scoping phase)?

- How is tokophobia defined in the research literature and how is this fear understood in relation to requests for CS (scoping phase)?

- What is the effectiveness of planned interventions offered to women requesting a CS due to tokophobia in affecting: choices about mode of birth; their fear and/or anxiety levels prior to childbirth; and their perceptions of the birth experience?

\section{Inclusion Criteria}

\section{Types of participants}

This review considered studies that included pregnant women (primiparas and/or multiparas) requesting a CS for tokophobia in the absence of medical (or obstetric) indications who were offered the opportunity to take part in a planned intervention. Studies in which the main focus was pregnant women with diagnosed mental health disorders were excluded.

\section{Types of interventions}

The quantitative component of this review considered studies that evaluated the effectiveness of planned interventions in reducing levels of fear and/or anxiety of women with tokophobia and final planned CS rates for these women.

Planned interventions included or took the form of:

- psychotherapeutic counselling; 
- relaxation sessions;

- $\quad$ psychosomatic support;

- $\quad$ obstetric or midwifery support;

- $\quad$ visits to maternity units;

- crisis-oriented counselling;

- cognitive therapy;

- individualised care plans.

A planned intervention for tokophobia was defined as at least one specific planned session with one or more of:

- an obstetrician;

- a doctor;

- a psychologist;

- a midwife;

- a therapist;

- a counsellor;

- a mental health nurse

- $\quad$ other suitably qualified healthcare professionals.

Simple advice and support given by maternity health professionals in the normal course of antenatal care (i.e. standard care) was not considered as a planned intervention for the purposes of this review although, where relevant, studies that used standard care as a comparator were taken into consideration.

\section{Phenomena of interest}

The phenomena of interest for the qualitative component of the review were to be the experiences of women with tokophobia who request a CS, particularly in terms of satisfaction with planned interventions and the subsequent childbirth experience. However, no relevant qualitative papers were found.

\section{Types of outcome measures}

The review planned to consider quantitative studies (or quantitative elements of mixed method studies) that included the following outcomes:

- $\quad$ final choice made for birthing (as measured by questionnaires, data extraction from hospital records and surveys);

- alteration in levels of fear and anxiety (as measured by validated instruments, visual analogue 
scales, data extraction from hospital records and questionnaires);

- satisfaction with the birth experience (as measured by validated instruments and questionnaires);

- $\quad$ satisfaction with, or perceived quality of, planned counselling (as measured by follow-up and feedback questionnaires).

No relevant qualitative studies were found but the review had planned to consider qualitative studies (or qualitative elements of mixed method studies) that included the following outcomes:

Women's experiences of making decisions, beliefs about childbirth, their expressed satisfaction with the birth experience and the planned intervention in question and their verbal recollection of their physical and psychological state during pregnancy and post-delivery (as explored using qualitative research methods, such as diaries, observation, interviews and focus groups).

\section{Types of studies}

The quantitative component of the review considered both experimental and epidemiological study designs including RCTs, non-randomised controlled trials, quasi-experimental, before and after studies, prospective and retrospective cohort studies, case control studies and cross sectional studies, as well as meta-analyses and systematic reviews, where available, for inclusion.

The qualitative component of the review set out to consider studies that focused on qualitative data including, but not limited to, designs such as phenomenology, grounded theory, ethnography, action research, feminist research and evaluation research. However, as no eligible qualitative papers were found, this element of the review did not take place.

\section{Search strategy}

The search aimed to find both published and unpublished studies in English distributed between January 1990 and April 2012. This timeframe was chosen because tokophobia was not recognised clinically until the mid-1990s and therefore did not appear in the literature before this period. A threestep search strategy was utilised. An initial limited search of MEDLINE, EMBASE and the Midwife Information and Resource Service (MIDIRS) was undertaken, followed by analysis of the text words contained in the title and abstract, and of the index terms used to describe the paper. A second search using all identified keywords and index terms was then undertaken across all included databases. Thirdly, the reference list of all identified reports and articles was searched for additional studies.

The databases searched were:

- EMBASE

- MEDLINE 
- MIDIRS

- The Cumulative Index to Nursing and Allied Health Literature (CINAHL)

- The Cochrane Library

- British Nursing Index (BNI)

- PsycARTICLES

- MedNar

- ProQuest Dissertations and Theses

Details of the search strategies for each of these databases are given in Appendix I.

Additionally, the following sources were accessed for conference papers, dissertations and theses and grey material:

- Confidential Enquiry into Maternal and Child Health (CEMACH)/ The Centre for Maternal and Child Enquiries (CEMACE) reports

- NICE guidelines

- Department of Health guidelines

- Royal College of Obstetricians and Gynaecologists (RCOG) green top guidelines

- Royal College of Midwives (RCM) position papers

- British Association of Counselling and Psychotherapy (BACP)

- British Psychological Society (BPS)

- EThOS-Beta database (British Library database of UK theses)

- EBSCO Psychology \& Behavioral Sciences Collection

The following journals were also searched by hand:

- Midwives (RCM journal)

- The Practising Midwife

- British Journal of Midwifery

These journals were hand searched, as they have only become accessible electronically only-within the last decade. Earlier issues may not have been indexed on databases.

Keywords used in the main search were:

- Counsel*; CBT; Cognitive Behavio?ral Therapy; Cognitive Therapy; Behavio* Therapy; Advice; Support; Therap*; Advocacy; Information; Psycholog*; Psychiatr*; Psychotherap*; Relaxation; Psychosomatic; Crisis Oriented Counse?ling [all combined with 'OR']. 
- C?esar?an Section (s); Section C?esar?an; Abdominal Deliver*; Deliver ${ }^{*}$ C?esar?an; C Section [all combined with 'OR'].

- To?ophobia; Parturiphobia; Fear; Anxiety; Fear of Childbirth; Childbirth Related Anxiety [all combined with 'OR'].

- Pregnancy; Antenatal; Ante Natal; Prenatal; Pre Natal [all combined with 'OR'].

- All above terms combined with 'AND'.

\title{
Method of the review
}

\begin{abstract}
Assessment of methodological quality
Research papers selected for retrieval were assessed by two independent reviewers for methodological validity prior to inclusion in the review. Standardised critical appraisal instruments from the Joanna Briggs Institute Meta Analysis of Statistics Assessment and Review Instrument (JBI-MAStARI) (Appendix II) were used. Any disagreements that arose between the reviewers were to be resolved through discussion, or with a third reviewer. However, there were no disagreements.
\end{abstract}

\section{Data collection/ extraction}

Quantitative data were extracted from papers included in the review using the standardised data extraction tool from JBI-MAStARI (Appendix III). Data extraction using JBI Qualitative Assessment and Review Instrument (JBI-QARI) was not necessary as there were no qualitative papers in the review.

\section{Data synthesis}

Although it had been planned to perform meta-analysis of the findings, it was not possible to pool quantitative results in a statistical meta-analysis using JBI-MAStARI, due to heterogeneity of interventions, methods and statistical analysis. Therefore, findings were presented in narrative form.

\section{Results}

\section{Description of studies}

The abstracts of a total of 281 potentially relevant papers were retrieved. After evaluation of the abstracts against the inclusion/ exclusion criteria, 262 papers were excluded. Full text articles were retrieved for the remaining 19 papers. -These full text articles were evaluated and nine were found to be irrelevant and excluded. The remaining ten articles were assessed for methodological quality, resulting in the exclusion of one paper. Thus nine papers were included in the review. However two of these papers ${ }^{15,55}$ appertained to the same study: the second paper reporting on follow up studies after the original intervention study and thus expanding on the results. For this reason, these two studies were treated as one for data extraction and analysis. A further study ${ }^{56}$ used some of the same data as the study by Nerum et al. ${ }^{31}$ However Halvorsen et al. ${ }^{56}$ also included new data from a different sample. 
Therefore these two papers were treated as separate studies. All of these studies were quantitative. Figure 1 outlines the selection and evaluation process involved in identifying relevant papers for this review. The papers excluded after review of the full text or after critical appraisal, and the reasons for exclusion, are found in Appendix IV. See Appendix V for a summary of the characteristics of the included studies.

Only one RCT ${ }^{21}$ was found. Of the remainder, five were case control studies. ${ }^{15,40,55,57-59}$ This included the two papers addressing the same study. ${ }^{15,55}$ Two studies were descriptive case series. ${ }^{31,56}$ All the studies were Scandinavian: four from Sweden; ${ }^{15 / 55,40,57,59}$ two from Finland ${ }^{21,58}$ and two from Norway. ${ }^{31,56}$ Sample sizes ranged from $86^{31}$ to $2662 .{ }^{40}$ 
Figure 1: Search and selection of studies

Potentially relevant papers

identified by literature search $\mathrm{N}=281$

Papers excluded after evaluation of

abstracts $\mathrm{N}=262$

Papers retrieved for detailed

examination against inclusion/

exclusion criteria $\mathrm{N}=19$

Papers excluded after review of full text $\mathrm{N}=9$

Papers assessed for methodological quality $\mathrm{N}=10$

Quantitative papers included $\mathrm{N}=8$

Qualitative papers included $\mathrm{N}=0$

Papers included in systematic review $\mathrm{N}=8$

Papers excluded based on methodological quality $\mathrm{N}=1$

*Two papers ${ }^{15,155}$ were combined at the analysis stage.

The studies included in this review met most of the criteria identified in the critical appraisal tools. For 
the case control studies there was some difficulty assessing whether study participants were all at the same point in the course of their condition. Some studies made attempts to recruit participants at the same point in pregnancy, whilst others recruited at the point when tokophobia was identified and the woman referred for specialist help. However, none of them set out to identify the point at which the woman had started to experience tokophobia and to recruit at a specific point in the progression of the condition, and indeed, for practical and ethical reasons, this would have been almost impossible to do. Assessment of the criteria for inclusion was somewhat problematic, as the sample often came from a pre-defined group, for example, women referred for counselling because of FOC and an accompanying request for $\mathrm{CS}$.

A brief description of each study, highlighting methodological issues is as follows:

In a case control study, Sjögren and Thomassen ${ }^{15}$ paired 100 women referred to a specialist outpatient clinic for FOC (study group) with 100 women matched for age, parity, gestational week, mode of delivery and date of delivery (reference group). In the follow up study, Sjögren ${ }^{55}$ surveyed 72 pairs from the original sample. The study measured obstetric outcomes and participants' satisfaction with the intervention. Although all women had consultations with the psychosomatic gynaecologist lasting for 45 minutes, the number of sessions and the type of counselling varied, with only 18 women accepting psychotherapeutic counselling. Thus, it would be difficult to replicate this study. However, the use of statistical measures to demonstrate the outcomes allows for clear comparisons.

The only RCT was carried out by Saisto et al. (2001) ${ }^{21}$ who assigned 176 women with FOC to intensive therapy $(n=85)$ or conventional therapy $(n=91)$ groups once FOC had been diagnosed through a diagnostic tool. Women with contraindications to vaginal delivery were excluded from the study. Three questionnaires were administered prior to randomisation, four weeks before the due date and at three months postpartum. These questionnaires assessed depression, anxiety and,

postnatally, satisfaction with childbirth. Women's wishes for delivery were recorded before the birth. However, numbers in this study are small and the study required specially trained staff to provide the intensive therapy.

Ryding et al. ${ }^{57}$ evaluated experience and satisfaction of women treated for FOC by a team of midwives who had undergone training in counselling. This case control study was retrospective; selfcompleted rating scales were sent to the women who had been treated from 1-14 months postnatally. The 53 women who returned questionnaires from the intervention group were compared with a group of 53 women matched for parity and mode of delivery from the birth register. The use of a recognised rating scale gives this study some rigour but the overall numbers of women is small and the results did not conclusively show the intervention to be effective.

In a case control study, Saisto et al. (2006) ${ }^{58}$ explored the effectiveness of five group sessions with a psychologist (including one session attended by a midwife) for women experiencing severe FOC. In this case control study the experimental group of 102 women was compared with 85 women with FOC who had conventional treatment consisting of two appointments with an obstetrician. This latter group was not homogenous, as it included those who declined to be in the intervention group and 46 other nulliparous women who attended the clinic with FOC prior to the experimental group 
commencing. Although the experimental group were asked to evaluate the helpfulness of the therapy, it is not clear that this was used for comparison across both groups. The authors acknowledge potential for bias in the allocation to the groups and the lack of psychometric measurements to measure outcomes.

Waldenström et al. ${ }^{40}$ used data from a sample of 2662 antenatal women in a case control study. Two postal questionnaires were sent, one at 16 weeks gestation and one at two months postpartum. The first identified women with FOC and also measured depression. The second questionnaire asked if the women had undergone counselling. Because most Swedish obstetric units had established Aurora (FOC) clinics, such counselling would have been readily available. On the basis of their responses to the question' How do you feel when thinking about labour and birth?', asked in the second trimester, the researchers categorised the groups into: A) women with very negative feelings about childbirth who underwent counselling, B) women with very negative feelings but who did not undergo counselling, C) women who did not express very negative feelings but underwent counselling and D) those who did not express negative feelings and did not undergo counselling (reference group). Thus, data was through self-completion and partly retrospective. Furthermore, the groups were defined following collection of the data. The study did not capture women's final decision for birth. Although this study reports findings from a large sample size and is prospective and longitudinal, the authors acknowledge its limitations; the fact that it is observational and may not have captured all the dimensions of FOC. The type of counselling used was not specified and could be variably applied throughout the different Aurora clinics across the country. This research report is-was presented as a part of a much larger study and would be difficult to reproduce.

In one of the two studies categorised as case series, Nerum et al. ${ }^{31}$ studied 86 women who had FOC and had requested a planned CS. Although the sample was divided into two groups, moderate $(n=28)$ and severe $(n=58)$ FOC, the intervention for each group was similar, with counselling by specially trained midwives. The study involved a highly specialised convenience sample with limitations for generalisability.

Halvorsen et al. ${ }^{56}$ studied the effectiveness of individually tailored counselling based on a patient oriented method. This was delivered by two midwives who had received training in mental health but whose approaches to counselling differed. The study, also categorised as case series, took place over two sample time frames. The first time frame used the sample described by Nerum et al. ${ }^{31}$ with a sample size of 86 . In the latter sample $(\mathrm{N}=107)$ the mode of counselling of one of the midwives changed. The samples were selected groups, which the authors acknowledge limits their findings.

Sydsjö et al., ${ }^{59}$ in another case control study, examined the records of 353 women (index group) who, following assessment, had been referred to the psychosocial obstetrics and gynaecology unit. These were compared with a reference group of 579 women without FOC who gave birth on the same day as the index group women. Delivery outcomes were recorded. However the groups were not comparable because more women in the index group had experienced previous CS or instrumental delivery and this would have predisposed to a higher CS rate. Moreover, the intervention consisted of several different components, and these were not applied consistently to all women in 
the index group. Despite involving a larger sample size, this study was descriptive, thus reducing its rigour.

Overall there was a lack of consistency between studies in how levels of FOC were determined, and in the scales used to measure outcomes. The interventions were variable between studies and in some cases within studies and there was a lack of consistency regarding the definition of FOC.

\section{Results}

No meta-analysis could be performed because of the heterogeneity of the studies. Therefore a narrative summary is used to report results. Variability in definitions of tokophobia, in the participants included in the studies, in types and complexity of interventions and in outcomes are explored below.

\section{Definitions of Tokophobia}

Variations in the diagnosis and definition of tokophobia are summarised in Appendix VI. Three studies $^{15 / 55,57,58}$ did not use tools to identify severe FOC in their recruited sample, but relied on the fact that women had been referred to a 'fear of childbirth team' or psychosomatic specialist clinics or teams, as evidence of tokophobia. Sjögren and Thomassen ${ }^{15}$ and Sjögren ${ }^{55}$ discussed severe FOC in terms of mental distress and anxiety about birth as well as previous experience of a complicated delivery. Ryding et al. ${ }^{57}$ discussed intense fear arising from such factors as terror of pain, vaginal rupture, losing one's baby or one's own life, losing self-control and being left without assistance in labour. They linked this to the woman's request for CS. Saisto et al. (2006) ${ }^{58}$ also indicated that FOC included women who requested a CS and discussed fears of pain, of losing control, incapacity to give birth and of becoming a parent.

The two linked studies ${ }^{31,56}$ used specific criteria to determine FOC. Nerum et al. ${ }^{31}$ suggested that a FOC with a concurrent request for CS delivery may be understood as a crisis reaction to which the impending birth activates previously unprocessed life events and problems. Fear of birth was graded and considered severe when four or five of the following variables were present (if there were three present the fear was defined as moderate): 1) sleep problems (worries and nightmares) and difficulty in concentrating that were a handicap in daily life; 2) physiological manifestations of anxiety, such as trembling, sweating, rapid pulse, and respiration or diffuse bodily pains that reduced daily functioning; 3) little or no insight into what the fear of birth represented (e.g. unprocessed prior traumatic experiences); 4) experience of a large degree of loss of control; and 5) fear of dying during pregnancy or birth. Halvorsen et al. ${ }^{56}$ used the same criteria as Nerum et al. ${ }^{31}$ to define severe and moderate FOC.

Three papers ${ }^{21,40,59}$ identified FOC through using recognised screening tools. Saisto et al. (2001) ${ }^{21}$ used a questionnaire developed by Areskog et al. ${ }^{60}$ The questionnaire included a ten-item scale with questions about women's experiences relating to delivery, for example, difficulties in relaxing when thinking about delivery, feelings of panic, fear of screaming uncontrollably, fear of giving birth and preference for CS. Five affirmative responses indicated referral for FOC. Sydsjö et al. ${ }^{59}$ used the Diagnostic and Statistical Manual of Mental Disorders, $4^{\text {th }}$ Edition (DSM IV) ${ }^{61}$ to diagnose tokophobia These authors discussed FOC in terms of both fear and anxiety, although the emphasis was on the 
concept of fear. Amongst others, they listed the causes of fear as fear of pain; of losing self-control; of proving physically or mentally inadequate during labour; and fear of dying. Waldenström et al. ${ }^{40}$ used the Swedish version of the Cambridge Worry Scale, ${ }^{62}$ alongside a single question asking women's feelings about labour and birth to identify women with FOC. They also measured depression using the Edinburgh Postnatal Depression Scale. ${ }^{63}$

Scales, such as the Wijma Delivery Expectancy/ Experience Questionnaire (W-DEQ), ${ }^{64}$ are designed specifically to measure levels of tokophobia. It is to be hoped that, should such scales be used, a greater level of comparability might be achieved in the identification of women suffering from tokophobia, thus enabling a body of systematic research to be built up from which firm conclusions can be drawn.

\section{Participants}

The method of defining, and thus selecting, participants described above was a key contributory factor in the heterogeneity of the papers as regards sampling. Variations in sampling are summarised in Appendix VII.

There was also variability in whether women with previous high risk pregnancies were included or not. Five studies $15 / 55,31,40,56,59$ included women in the intervention groups who had experienced a previous CS, making the likelihood of another CS delivery more probable, regardless of the effectiveness of the intervention in reducing fear. However, because women with complicated births seem more likely to develop secondary tokophobia, to omit such women from the sample is to ignore a sizeable proportion of the women who need help with tokophobia.

The remit of this review was to exclude studies focussing on pregnant women with diagnosed mental health disorders and this was adhered to. No papers were included that selected participants from psychiatric clinical populations. However, it was found that although some papers specifically excluded women with psychiatric conditions ${ }^{57,58}$ several others ${ }^{15 / 55,31,56}$ made reference to the fact that some women within the recruited sample were, on enquiry, found to have a history of mental illness or psychological problems. In view of the fact that tokophobia in itself is sometimes considered a psychiatric diagnosis ${ }^{1}$ this, on reflection, was not surprising. However the authors were contacted for further information on the numbers of such women in the sample. In the case of one study, ${ }^{15 / 55}$ sadly, the first author was deceased and the second could not be located. However the authors of the other three papers ${ }^{31,40,56}$ responded.

Correspondence with Lotta Halvorsen revealed that, among the 2000-2002 sample of 86, ${ }^{31,56} 18$ had psychiatric diagnosis: three in the moderate fear group; and 15 in the severe fear group. In the moderate fear group, two had personality disorders and one had obsessive compulsive disorder (OCD). In the severe fear group,- two -had -previous -psychoses, -four had OCD, -seven had posttraumatic stress disorder (PTSD) and two had personality disorders. In addition, some had an anxiety and/or depression diagnosis and/or eating disturbances. From the 2004-2006 sample ${ }^{56}$ of 107 women, there were 25 women with psychiatric diagnoses: two with schizophrenia; four with previous psychoses; 11 with PTSD; six with OCD and two with bipolar disorder. The authors reported that most

Commented [RC-J4]: Need to tidy ths formatting as occurs throughout this paragraph 
women in this sample had anxiety and/or depression and eating disorders. However as anxiety is an integral aspect of tokophobia it is difficult to determine the significance of this. Gunilla Sydsjö was also contacted, as although referral and treatment for any kind of psychosocial problem was an exclusion criterion for the reference group, these women were apparently included for the index group. ${ }^{59}$ Sydsjö reported that the women in the index group were considered to have severe maternal FOC according to DSM-IV or a clinical diagnostic interview. Only women who had severe FOC were included and women with psychosis were excluded. Sydsjö had no knowledge of whether there were women with personality disorders or other mental health disorders in the index group.

However, as discussed previously, it appears that mental health disorders will often be present in women with tokophobia. Thus, the pragmatic decision was taken to include such studies as their sole focus was not women with mental health issues, and to exclude such women would have resulted in atypical samples.

Another area of heterogeneity was in the features of the comparison group. Four studies compared tokophobic women with non-tokophobic women. ${ }^{15 / 55,40,57,59}$ This raises problems in identifying the effectiveness of interventions as, taking into consideration the profound nature of tokophobia, it seems reasonable to argue that any intervention is unlikely to resolve the condition to the extent that outcomes are as positive as they would be in a non-tokophobic sample. In the remaining papers comparison groups were also tokophobic. In the case of Saisto et al. (2001), ${ }^{21}$ the only RCT included in this review, women identified to be tokophobic were randomised to receive intensive treatment or routine obstetric care. The comparison group in Saisto et al. (2006) ${ }^{58}$ consisted of women who did not wish to receive counselling (whose tokophobia may therefore be qualitatively different in some way), as well as those who had sought help for FOC outside of the period of the intervention. Nerum et al ${ }^{31}$ compared outcomes for women with moderate and severe fear of birth. Halvorsen et al. ${ }^{56}$ compared outcomes for tokophobic women allocated to two midwives with different counselling approaches. Allocation was according to the midwives' capacity but it was noted that there were differences in the numbers of women with high obstetric risk in each group. Therefore, even when two tokophobic groups were compared, in all of the studies except Saisto et al. (2001), ${ }^{21}$ there was the potential for confounding factors to be present.

\section{Interventions}

Although all the interventions consisted of therapy or counselling, there was wide variability in the type of support offered, the frequency of the support, and the staff involved in giving the support (see Appendix VIII). In all but two of the studies ${ }^{21,58}$ the intervention was administered on a one-to-one basis. The RCT ${ }^{21}$ used therapeutic group sessions with relaxation exercises and in Saisto et al. $(2006)^{58}$ the mode of delivery is unclear. In several of the studies ${ }^{15 / 55,21,31,56}$ the number of intervention sessions is unspecified, the support being tailored to the needs of the individual woman. In three of the remaining papers ${ }^{40,57,59}$ not all participants received the same number of visits. Only in the Saisto et al. (2006) ${ }^{58}$ study did all participants receive the same number of sessions (five group sessions)

In the Sjögren and Thomassen ${ }^{15}$ and Sjögren ${ }^{55}$ study, women were assessed for the ability of the individual woman to accept psychotherapy. All women had consultations with a specialist who was 
both a gynaecologist and psychotherapist and 25 women also had psychotherapy. In the consultations, efforts were made to encourage women to express their fears, the aim being to identify the components of anxiety and to encourage consideration of vaginal delivery. Partners were encouraged to be involved in the discussion. Information was recorded in the women's notes for the delivery staff to read.

Saisto et al. (2001) $)^{21}$ used what is described as 'intensive therapy': appointments providing information and conversation regarding previous obstetric experiences, feelings and misconceptions. It is not clear whether this was individually or in groups. These appointments were with an obstetrician trained in childbirth psychology, and cognitive therapy consisted of combined CBT and psychotherapy with self-reflection. An appointment was also made with a midwife for visits to the obstetric ward and information about pain relief and possible obstetric interventions. Written information was given about the pros and cons of CS and vaginal birth and on alternative forms of pain relief. At the last appointment the written wishes of the women were documented and attached to the records. Women were able to contact the therapist or midwife between sessions, if needed.

Ryding et al. ${ }^{57}$ explored the outcomes of women referred to the hospital's 'fear of childbirth team'. The members of this team were described as midwives who worked on the maternity unit and who had received counselling preparation. The authors reported that the 'fear of childbirth team' encouraged women to talk about the nature of their fear, and previous traumatic birth experiences. A birth plan was then developed and the woman was psychologically prepared for the prospect of giving birth.

Saisto et al. (2006) ${ }^{58}$ used therapeutic group sessions with relaxation exercises. These were led by a psychotherapist but a midwife joined one of the sessions. The groups met once a week for five weeks. Each session lasted 120 minutes and comprised discussions of labour and pain relief options, visualisation and relaxation exercises. One session also gave the women the opportunity to express their wishes in notes for their midwife.

In a large multi-centred comparative study, Waldenström et al. ${ }^{40}$ explored the efficacy of the Swedish Aurora clinics, established to treat FOC. The clinic teams consisted of midwives supported by an obstetrician, psychologist, social worker and sometimes a psychiatrist. Referral to the Aurora clinics appeared to take place at any time in pregnancy and most counselling was undertaken by a midwife. The following types of interventions could be involved: the teaching of relaxation techniques; a visit to the local delivery ward as part of the counselling; development of a birth plan; and the involvement of an obstetrician when CS or other obstetric interventions were being considered by the woman.

Nerum et al. ${ }^{31}$ used crisis-oriented counselling, described as a 'patient orientated approach' in which childbirth concerns, life situations and solutions other than giving birth by planned CS were explored. The team consisted of an obstetrician, two experienced midwives and a social worker. Two hours were given for the first appointment and further sessions were individually planned. Towards the end of pregnancy, plans were made for birth. 
Halvorsen et al. ${ }^{56}$ explored the role of the two midwives in the study above, who had both received training in mental health but whose approaches to counselling differed. One midwife used a 'coping' attitude to counselling, communicating various ways a woman could be helped to give birth vaginally, indicating that this would be best for both mother and baby. The other midwife also communicated that vaginal birth was preferable, but indicated that the woman had the ultimate choice as to mode of birth and that this would be supported and respected ('autonomy' attitude). Both midwives, however, based their approach on an initial mental health assessment that explored sleep and concentration problems, physiological manifestations of anxiety and lack of insight into what the fear of birth represented, experiences of loss of control and fear of dying during pregnancy or birth. In the second sample the 'coping attitude' approach was used by both midwives

Women with FOC recruited to the Sydsjö et al. ${ }^{59}$ study received individualised psychological support and psychoeducation about pain relief and the risks and benefits of vaginal delivery. The number of sessions varied and included: meetings with a specially trained midwife (47.3\%) between 1-7 sessions; consultation with an obstetrician (67.7\%) between 1-5 sessions; and consultation with a psychotherapist or psychologist (32.4\%) between 1-10 sessions. Staff were trained in psychoeducational and CBT strategies.

As discussed in the introduction to this review, a question to be considered iswas: who is best placed to provide interventions for women with tokophobia? All the studies involved either a practitioner in psychological therapies (for example, a psychologist or psychotherapist) or one or more obstetricians or midwives who had received some training in counselling, mental health or psychology. Five of the studies ${ }^{21,31,40,57,59}$ also involved midwives and obstetricians and thus this appeareds to be the combination of choice. Sjögren and Thomassen ${ }^{15}$ and Sjögren ${ }^{55}$ used a psychosomatic specialist who was qualified as a gynaecologist and psychotherapist but who also sought advice from an obstetrician when a woman's history was obstetrically complicated. Halvorsen et al. ${ }^{56}$ involved midwives trained in mental health.

Although the interventions varied greatly, there were several elements that recurred across many of the studies. These were: encouraging the woman to express or discuss her fears; discussion and information provision around mode of birth, often including discussion of the risks and benefits of vaginal birth and CS; planning for the birth, often involving the development of a birth plan and visits to delivery suites. Less commonly interventions included relaxation strategies (used by Saisto et al. $(2006)^{58}$ and Waldenström et al. ${ }^{40}$ ) and the involvement of partners (used by Sjögren and Thomassen ${ }^{15}$ and Sjögren ${ }^{55}$ ).

\section{Outcomes}

Final Birth Choice. 
Findings from the studies are summarised in Appendix IX as regards the outcomes of interest. Not all papers reported on all of these outcomes and some studies examined final birth outcome rather than the woman's final choice. There is an important distinction between the two; women may elect to give birth vaginally but then end up having CS for obstetric reasons. Although an initial examination of the outcomes shows variability between papers in the success of the intervention, it is important to relate this to the research design as some control groups were tokophobic and some were not, thus giving the results a different meaning.

Of the studies that did record final birth choice, ${ }^{15 / 55,21,31,56,58,59}$ in Sjögren and Thomassen ${ }^{15}$ and Sjögren, ${ }^{55}$ controls were found and matched after the intervention group had given birth, so no comparison could be made as to whether birth outcomes were improved with the intervention. Nerum et al. ${ }^{31}$ found that 74 women (86\%) changed their choice to vaginal birth after the intervention. Moreover, $93 \%$ of the respondents expressed a preference for vaginal birth in the future, including $46 \%$ of the women who had been delivered by CS. However there was no comparison group in this study. Using the same data, Halvorsen et al. ${ }^{56}$ found that significantly more women treated by the midwife with a 'coping' attitude changed their initial request for CS compared with women counselled by the midwife with an 'autonomy' attitude. In the second sample, when both midwives adopted the 'coping' attitude, the percentages of women deciding to plan for vaginal birth were high (97\% and $93 \%$ ) and not significantly different. Thus the approach taken by counsellors needs serious consideration in future studies.

Only two studies compared birth choices in groups of tokophobic women. In the only RCT, Saisto et al. $(2001)^{21}$ found no difference between the two groups in changes to birth choice when intensive and conventional therapy were compared. However, using group therapy, Saisto et al. (2006) ${ }^{58}$ found that significantly more women in the experimental group chose to attempt vaginal birth. Nevertheless it must be noted that the participants in the comparison group included women who had declined the group therapy sessions. These women may have had a qualitatively different attitude to birth from the experimental group, possibly preferring the option of CS as a way to manage their fears rather than interventions to overcome them.

\section{Alterations in Fear or Anxiety.}

Considering that the key feature of tokophobia is fear, it is interesting that only one study ${ }^{21}$ recorded alterations in fear or anxiety as an outcome. Saisto et al. $(2001)^{21}$ found that concerns about the birth decreased significantly in the intensive therapy group, whilst actually increasing in the conventional therapy group. Although Saisto et al. $(2006)^{58}$ did not measure fear as an outcome, they did find that the ability to share feelings was one of the factors that helped relieve the fears of women in the experimental group and that this factor was considered more helpful than receiving information. 
Five studies recorded some aspect of satisfaction with childbirth. ${ }^{15 / 55,21,31,40,57}$ In two studies ${ }^{21,57}$ the interventions resulted in more negative experiences of birth. Saisto et al. (2001) ${ }^{21}$ found that women in the intensive therapy group reported feeling less safe during the birth than women in the control group. As this was an RCT, it is possible that participants did not always receive the intervention of their choice and that this undermined their confidence during birth. In the study by Ryding et al. ${ }^{57}$ the study group women found birth a significantly more negative and frightening experience than women in the comparison group. However, the comparison group were non-tokophobic so, whilst it is disappointing that the study group's fears were not ameliorated to the same level, it is not surprising Two of the remaining studies, however, found the intervention to have a positive effect, whilst one found a negative effect for the non-intervention group. At 1-3 year follow up, Sjögren ${ }^{55}$ found that significantly more study group women remembered the birth as easier than expected. These women reported that they had felt in command of the delivery, although the intervention had not increased their satisfaction with care. Nerum et al. ${ }^{31}$ did not specifically measure satisfaction with the birth. However the fact that $93 \%$ of the respondents expressed a preference for vaginal birth in the future, suggests that satisfaction levels were high. Waldenström et al. ${ }^{40}$ found that although the satisfaction with birth of the groups that had counselling was no greater than the other two groups, the women who expressed FOC but had no counselling were significantly more likely to assess the birth experience as negative.

\section{Satisfaction with Counselling}

Four studies explored satisfaction with the intervention as an outcome. ${ }^{31,55,57,58}$ Sjögren ${ }^{55}$ found that the intervention did not increase the study group's satisfaction with care. Indeed, this group made substantially more comments than the matched controls about how care could be improved. However in the other three studies, the intervention was evaluated more positively. Ryding et al. ${ }^{57}$ found that significantly more study group women than controls reported fulfilled expectations with their care, whilst Saisto et al. (2006) ${ }^{58}$ found that group sessions were more positively evaluated than relaxation sessions. Despite the lack of a comparison group, the study by Nerum et al. ${ }^{31}$ also suggests that the intervention was positively received by the women, with $98 \%$ of the sample, including all the women who had changed their request from CS to vaginal birth, expressing satisfaction with the counselling service.

Once again, the wide variations in interventions across the studies, as well as their complex nature, make it difficult to draw any conclusions as to which elements of the interventions led to satisfaction, although there is evidence that being part of a group with similar concerns was a positive factor for the participants in the Saisto et al. (2006) ${ }^{58}$ study. It is also worth noting that the three studies in which the interventions were positively evaluated all involved midwifery input. In each case, the midwives helped the woman prepare for birth and make a detailed birth plan, whilst in the Sjögren and Thomassen ${ }^{15}$ and Sjögren ${ }^{55}$ study the specialist administering the intervention was a gynaecologist and psychotherapist. This study also involved in-depth exploration of the women's feelings and fears as well as, where necessary, planning obstetric interventions. Women's needs and wishes were recorded in their notes for the delivery room staff to read. So, although no midwife was involved, the 
care was very similar. Nevertheless it could be postulated that it may be the different focus of the midwife that women find helpful.

\section{Discussion}

The heterogeneity of the studies examined above makes it difficult to infer the effectiveness of the various interventions for tokophobia. Indeed, it transpires that the definition of tokophobia itself requires clarification. However with the availability of scales such as the W-DEQ, ${ }^{64}$ designed specifically to measure levels of tokophobia, there is no reason why a greater level of consistency across research samples might not be reached.

Commented [RC-J5]: Are you able to put in here when the scale was developed

Nevertheless, even with the tightening of definitions, decisions still need to be made as to whether to include women with mental health conditions in such research. As explained previously, it seems that tokophobia and mental health cannot be so easily separated as was assumed when the protocol for this review was developed. The question remains as to whether women with mental health problems should be eliminated from this research, or whether this would mean that the requirements of those most in need of help would not be addressed. What is clear, however, is that a mental health assessment should be used to identify which women in the sample do have mental health problems, and what those problems are, so that this can be factored into the findings.

Similarly the differentiation between multigravid and primiparous women needs to be explored. In some studies in this review there was a lack of clarity in the sampling as regards this issue. Multigravid women with tokophobia are more likely to be fearful due to previous birth experiences. The question, therefore, is whether their fears are thus so qualitatively different to those of primigravid women that the two groups should be studied separately. Moreover, some primigravid women develop the belief that vaginal birth is hazardous, and with concomitant fear, ${ }^{65}$ as a result of birth stories told to them by friends and family. For others it seems that psychosocial or psychological factors lie at the root. So the question might be asked as to whether women who develop fears from a vicarious experience of a friend or family member's birth are likely to have more in common with multigravid women than with primigravidae whose fears arise out of other factors. Such issues require further study. However, most certainly future research should clearly identify the parity of those being studied and explore differences in outcomes resulting from this.

Another important factor to be differentiated, particularly when birth decisions are being considered as an outcome, is whether women have a past history (in this or a previous pregnancy) of high risk obstetric factors. Not only might these women have greater reasons to fear birth, but the factors themselves, rather than the management of tokophobia, may drive decisions about mode of delivery.

The capacity of interventions for tokophobia to change women's decisions for CS is not proven. The differences in approach in the studies above were diverse, with some being complex interventions using psychotherapeutic styles and others using varied forms of counselling. Therefore, it is difficult to draw conclusions about effectiveness. It is unclear how some of the simpler strategies for intervention, i.e. detailed information giving, explanations about pain relief, tailored birth plan development, and writing requests in the notes and delivery unit visits, could reduce tokophobia. 
Nevertheless, the fact that some positive findings did arise out of the studies discussed above, suggests that this issue should continue to be explored, paying attention to the attitude of those administering the intervention as well as the nature of the intervention itself. The use of group therapeutic interventions also warrants further investigation. It seems that the opportunity to discuss fears with other mothers-to-be, and perhaps thus to establish the fact that such fears are not unique to the sufferer, could be a positive factor in the treatment of tokophobia. ${ }^{58}$

The nature of the person providing the intervention should be examined in future research. It appears that anyone who offers counselling or support for tokophobia would require specific training for this to be effective, however Halvorsen et al. ${ }^{56}$ have shown how a positive coping attitude on behalf of the counsellor can also make a difference to women's birth decisions. It is interesting that midwives were involved in the three studies in which the interventions were positively evaluated and it is possible that the unique focus that midwives take towards childbirth was a contributory factor. Nevertheless this also requires further investigation.

It is a matter of concern that research looking to find interventions for tokophobic women should so often fail to consider a reduction in fear as a relevant outcome. The limited evidence that exists suggests that intensive therapy, such as that used by Saisto et al. (2001), ${ }^{21}$ consisting of information, exploration of feelings and anxieties and CBT, may reduce fear. The work of Saisto et al. (2006) ${ }^{58}$ suggests that being able to share feelings may be the effective element in this complex intervention. Future research should focus on identifying the relevant factors, as it is possible that complex and expensive interventions may not be entirely necessary. Moreover it is surely indefensible to study tokophobia without considering fear reduction as a valid outcome. The amelioration of women's distress must be a priority even if her plans for CS remain unchanged.

This review has elicited very limited evidence for the effectiveness of interventions in increasing tokophobic women's satisfaction with childbirth. However, satisfaction with childbirth has, for a long time, been considered a difficult construct because of the diverse contributory factors and because of the tendency for women to feel loyal to their own birth and thus to rate their experiences highly. $66,67,68,69$ Lumley ${ }^{66}$ notes that women's satisfaction with their childbirth experience can alter over the postnatal period. This assertion is supported by Hollins Martin and Fleming ${ }^{69}$ who observed that women's constructs of a rewarding birth experience are directed by personal beliefs, reactions, emotions and reflections, which can alter in relation to such factors as mood, disposition and the context in which the woman is being asked. Again, the heterogeneity in the way the studies measured satisfaction makes it difficult to draw comparisons and it seems logical to recommend that future research should measure satisfaction on more than one occasion and by using more than one parameter to elicit a more comprehensive understanding of the women's feelings about their birth experience.

An overarching issue is the way that tokophobia should be researched in the future. Despite the fact that one RCT exists, some researchers argue that it is unethical to allocate or withhold care in a random fashion to tokophobic women who are seeking help. ${ }^{57}$ However, to take a non-tokophobic sample as the comparator, as have some of the studies in this review, means that outcomes will 
almost inevitably be different, if only for the fact that the tokophobic women are also more likely to have high risk pregnancies or mental health issues. To compare tokophobic women who agree to interventions with tokophobic women who refuse them also raises issues around fundamental differences in the psychological status, or level of fear, of the members of each group. Best practice might therefore be to compare different treatments and this might be possible as an RCT albeit in the absence of a 'no treatment' control. Alternatively a 'before and after' design may be usefully employed, measuring levels of fear prior to, and after, the administration of an intervention.

\section{Conclusion}

In conclusion, more research is needed to help understand how women with this distressing condition might be helped. The current NICE guidelines, ${ }^{48}$ which state that tokophobic women should be offered interventions such as CBT; support from a named member of the maternity team; carer continuity; and formal counselling can be upheld for the time being, in the absence of any additional evidence, although it should be noted that there is currently no reason to support CBT over and above other interventions.

\section{Implications for practice}

Implications for practice are limited due to the heterogeneous nature of the research explored in this review, making it impossible at this stage to draw firm conclusions about best practice. The research to date suggests that midwifery involvement with tokophobic women is to be recommended and that psychological interventions should be delivered by suitably trained individuals. There is also some evidence that women find it helpful to talk to other women with similar fears.

However, the imperative is for further research to clarify which interventions are effective, and how and by whom they are best administered.

\section{Implications for research}

- $\quad$ RCTs comparing different treatments should be considered

- 'Before and after' studies should be considered

- Group interventions should be explored further

- More research is needed exploring the roles that midwives can play in administering interventions

- Definitions of tokophobia - a scale such as the W-DEQ should be agreed upon as the standard measure for FOC

- It may be useful to have, associated with a definition, a taxonomy for levels of tokophobia

- Mental health assessment should be used to identify women with mental health problems in research samples

- Parity must be recorded and differential outcomes presented

- Obstetric risk factors must be recorded and taken into account in analysis of outcomes

- Reduction of fear should always be considered as an outcome 
- Satisfaction with labour and birth outcome should be measured on more than one occasion and by using more than one parameter to elicit a more comprehensive understanding of women's feelings about their birth experience.

\section{Conflicts of interest}

None.

\section{Acknowledgements}

Our thanks go to Heather Loveday and Dave Sookhoo both of the University of West London (UWL) for their help, advice and support and also to Marc Forster and Maria D'Souza, UWL Librarians, for their assistance in obtaining papers.

\section{References}

1. Hofberg K, Brockington IF. Tokophobia: an unreasoning dread of childbirth. A series of 26 cases. Brit J Psychiat. 2000;176:83-5.

2. Laursen M, Hedegaard M, Johansen C; Danish National Birth Cohort. Fear of childbirth: predictors and temporal changes among nulliparous women in the Danish National Birth Cohort. BJOG. 2008;115(3):354-60.

3. Saisto T, Halmesmaki E. Fear of childbirth: a neglected dilemma. Acta Obstet Gyn Scan. 2003;82:201-8.

4. Hofberg K, Ward M. Fear of childbirth, tocophobia and mental health in mothers: the obstetricpsychiatric interface. Clin Obstet Gynecol. 2004;47:527-34.

5. Ventura SJ, Martin JA, Curtin SC, Mathews TJ, Park MM. Births: final data for 1998. National Vital Statistics Report. 2000;48:1-100.

6. Hospital Episode Statistics. NHS Maternity Statistics 2009-2010. 2011; Available from: http://www.hesonline.nhs.uk/Ease/servlet/ContentServer?sitelD=1937\&categorylD=1475.

7. World Health Organization. Appropriate technology for birth. Lancet. 1985;2:436-7.

8. Savage W. The rising caesarean section rate: a loss of obstetric skill? J Obstet Gynaecol. 2007;27:339-46.

9. Maternity Care Working Party. Making normal birth a reality. Consensus statement from the Maternity Care Working Party: our shared views about the need to recognise, facilitate and audit normal birth 2007; Available from: http://www.rcog.org.uk/files/rcog-corp/uploadedfiles/JointStatementNormalBirth2007.pdf.

10. World Health Organization. Caesarean section without medical indication. Policy Briefing. Geneva: WHO; 2010.

11. Levine EM, Ghai V, Barton JJ, Strom CM. Mode of delivery and risk of respiratory distress after elective delivery at "term". Obstet Gynecol. 2001;97:439-42.

12. Madar J, Richmond S, Hey E. Surfactant-deficient respiratory distress after elective delivery at "term". Acta Paediatr. 1999;88:1244-8. 
13. Nissen E, Uvana-Moberg K, Svensson K, Stock S, Widstrom A-M, Winberg J. Different patterns of oxytocin, prolactin but not cortisol release during breastfeeding in women delivered by caesarean section or by the vaginal route. Early Hum Dev. 1996;45:103-18.

14. Liu S, Liston RM, Joseph KS, Heamna M, Sauve R, Kramer MS. Maternal mortality and severe morbidity associated with low-risk planned cesarean delivery versus planned vaginal delivery. CMAJ. 2007;176:455-60.

15. Sjögren B, Thomassen P. Obstetric outcome in 100 women with severe anxiety over childbirth. Acta Obstet Gyn Scan. 1997;76:948-52.

16. Gamble JA, Creedy DK. Women's request for a cesarean section: a critique of the literature. Birth. 2000;27(4):256-63.

17. Weaver J. Caesarean section and maternal choices. Fetal Matern Med Rev. 2004;15:1-25.

18. Thomas J, Paranjothy S. Royal College of Obstetricians and Gynaecologists Clinical Effectiveness Support Unit. The National Sentinel Caesarean Section Audit Report. London 2001.

19. Wagner M. Critique of British RCOG National Sentinel Caesarean Section Audit Report of Oct 2001. MIDIRS. 2001;12:366-70.

20. Ryding EL. Investigation of 33 women who demanded a caesarean section for personal reasons. Acta Obstet Gyn Scan. 1993;72:280-285.

21. Saisto T, Salmela-Aro K, Nurmi J, Könönen T, Halmesmäki E. A randomized controlled trial of intervention in fear of childbirth. Acta Obstet Gyn Scan. 2001;98:820-6.

22. Robson S, Carey A, Mishra R, Dear K. Elective caesarean delivery at maternal request: a preliminary study of motivations influencing women's decision-making. Aust NZ J Obstet Gyn. 2008;48:415-20.

23. Weaver J, Statham H, Richards M. Are there "unnecessary" cesarean sections? Perceptions of women and obstetricians about cesarean sections for nonclinical indications. Birth. 2007;34:3241.

24. Wiklund I, Edman G, Ryding EL, Andolf E. Expectation and experiences of childbirth in primiparae with caesarean section. BJOG. 2008;115:324-31.

25. Gamble JA, Creedy DK. Women's Preference for a Cesarean Section: Incidence and Associated Factors. Birth. 2001;28(2):101-110.

26. Nilstun T, Habiba M, Lingman G, Saracci R, Da Frè M, Cuttini M. Cesarean delivery on maternal request: Can the ethical problem be solved by the principlist approach. BMC Med Eth. 2008;9:11.

27. Ryding EL. Psychosocial indications for cesarean section. A retrospective study of 43 cases. Acta Obstet Gyn Scan. 1991;70:47-49.

28. Rouhe H, Salmela-Aro K, Gissler M, Halmesmäki E, Saisto T. Mental health problems common in women with fear of childbirth. BJOG. 2011;118(9):1104-11.

29. Munro S, Kornelsen J, Hutton E. Decision making in patient-initiated elective cesarean delivery: the influence of birth stories. J Midwifery Wom Heal. 2009;54(5):373-379.

30. Otley $\mathrm{H}$. Fear of childbirth: understanding the causes, impact and treatment. Br J Midwifery. 2011;19:15-20. 
31. Nerum H, Halvorsen L, Sørlie Tand Øian P. Maternal request for caesarean section due to fear of birth: can it be changed through crisis-oriented couseling? Birth. 2006;33:221-228.

32. Melender H-L. Experiences of fears associated with pregnancy and childbirth: a study of 329 pregnant women. Birth. 2002;29:101-11.

33. Walsh D. Fear of labour and birth. Br J Midwifery. 2002;10:78.

34. McGrath P, Ray-Burrel G. The easy option? Australian findings on mothers' perception of elective Caesarean as a birth choice after a prior caesarean section. Int J Nurs Pract. 2009;15:271-279

35. Onley D. Investigating the psychological factors underlying tokophobia in women following birth trauma, and the need for psychological counselling of women who fear and avoid childbirth. D Couns Psych Thesis. 2008; Wolverhamption: University of Wolverhamption.

36. Rando PH, Ferreira RF, Nogueira F, Ribeiro MC, Lobar H, Artes R. Maternal psychological stress and distress as predictors of low birth weight, prematurity and intauterine growth retardation. Eur J Clin Nutr. 2003;57(2):266-272.

37. Cumberland S. Cause for concern (part 2): is there a correlation between fear of childbirth and caesarean section? MIDIRS. 2010;20(4):439-444

38. Ryding EL, Wijma K, Wijma B. Predisposing psychological factors for posttraumatic stress reactions after emergency cesarean section. Acta Obstet Gyn Scan. 1998;77:351-352

39. Johnson R, Slade P. Does fear of childbirth during pregnancy predict emergency caesarean section? BJOG. 2002;109:1213-1221.

40. Waldenström U, Hildingsson I, Ryding EL. Antenatal fear of childbirth and its association with subsequent caesarean section and experience with childbirth. BJOG. 2006;113:638-646.

41. National Collaborating Centre for Women's and Children's Health. Caesarean section. London: NICE; 2004

42. Warwick C. Rising caesarean section rate: a pulic health issue. Br J Midwifery. 1999;7:731.

43. Chaillet N, Dube E, Dugas M, Francoeur D, Dube J, Gagnon S, et al. Identifying barriers and facilitators towards implementing guidelines to reduce caesarean section rates in Quebec. B World Health Organ. 2007;85:733-820.

44. Royal College of Midwives. Caesarean section rate still too high, more one-to-one care needed to support women before and after birth, says RCM responding to new maternity figures. Redactive Publishing Ltd.; 2011; Available from: http://www.rcm.org.uk/college/about/mediacentre/press-releases/caesarean-section-rate-still-too-high-says-rcm-responding-to-newmaternity-figures-1-12-2011/

45. Lavender T, Hofmeyr GJ, Neilson JP, Kingdon C, Gyte GML. Caesarean section for non-medical reasons at term. Cochrane Database Syst Rev. 2006;Art. No: CD004660(3).

46. Smith E, Nolen-Hoeksema S, Fredrickson B, Loftus GR, editors. Atkinson \& Hilgard's Introduction to Psychology. London: Wadsworth; 2003.

47. Behague DP, Victora CG, Barros FC. Consumer demand for caesarean sections in Brazil: Informed decision making, choice or social inequality? A population based birth cohort study linking ethnographic and epidemiological methods. BMJ. 2002;324:942-5. 
48. National Institute for Clinical Excellence. Caesarean Section. London: RCOG Press; 2011.

49. Wiklund I, Edman G, Ryding EL, Andolf E. Expectation and experiences of childbirth in primiparae with caesarean section. BJOG. 2008;115:324-331.

50. Maznin NLB, Creedy DK. A comprehensive systematic review of factors influencing women's birthing preferences (protocol). Joanna Briggs Institute; 2009; Available from: http://connect.jbiconnectplus.org/ViewSourceFile. aspx?0=4612.

51. Horey D, Weaver J, Russell H. Information for pregnant women about caesarean birth. Cochrane Database Syst Rev. 2004;Art. No.: CD003858(1).

52. Bastos MH, Bick D, Rowan CJ, Small R, McKenzie-McHarg K. Debriefing for the prevention of psychological trauma in women following childbirth (protocol) Cochrane Database Syst Rev. 2008;Art. No.: CD007194(2).

53. Lal M. Psychosomatic approaches to obstetrics, gynaecology and andrology - a review. J Obstet Gynaecol. 2009;29:1-12.

54. Khunpradit S, Tavender E, Lumbiganon P, Laopaiboon M, Wasiak J, Gruen RL. Non-clinical interventions for reducing unnecessary caesarean section. Cochrane Database Syst Rev. 2011;Art No,: CD005528(6).

55. Sjögren B (1998) Fear of childbirth and psychosomatic support: a follow up of 72 women. Acta Obstet Gyn Scan. 1998;77:819-825.

56. Halvorsen L, Nerum H, Sørlie T, Øian P. Does counsellor's attitude influence change in a request for a caesarean in women with fear of birth? Midwifery. 2010;26:45-52.

57. Ryding EL, Persson A, Onell C, Kvist L. An evaluation of midwives' counselling of pregnant women in fear of childbirth. Acta Obstet Gyn Scan. 2003.82:10-17.

58. Saisto T, Toivanen R, Salmela-Aro K, Halmesmäki E.Therapeutic group psychoeducation and relaxation in treating fear of childbirth. Acta Obstet Gyn Scan. 2006;85:1315-1319.

59. Sydsjö G, Sydsjö A, Gunnervik, Bladh M, Josefsson A. Obstetric outcome for women who received individualized treatment for fear of childbirth during pregnancy. Acta Obstet Gyn Scan. 2012;91:44-49.

60. Areskog B, Kjessler B, Uddenberg N. Identification of women with significant fear of childbirth during late pregnancy. Gynecol Obstet Inves. 1982;13:98-107

61. American Psychological Association. Diagnostic and statistical manual of mental disorders. 4th edition. Washington, D.C.: APA; 1994.

62. Georgsson Öhman S, Grunewald C, Waldenström U. Women's worries during pregnancy: testing the Cambridge Worry Scale on 200 Swedish women. Scand J Caring Sci. 2003;17:148-152.

63. Cox JL, Holden JM, Sagovsky, R. Detection of postnatal depression. Development of the 10-item Edinburgh Postnatal Depression Scale. Br J Psychiat. 1987;150:782-786.

64. Wijma K, Wijma B, Zar M. Psychometric aspects of the W-DEQ: A new questionnaire for the measurement of fear of childbirth. Journal of Psychosomatic Obstet Gynecol. 1998;19:84-97.

65. Weaver J. Talking about caesarean section. MIDIRS. 2000; 10:487-490.

66. Lumley J. Assessing satisfaction with childbirth. Birth. 1985;12:141-145. 
67. Shearer MH. Commentary: how well does the LADSI measure satisfaction with labour and delivery. Birth. 1987;14:130-131.

68. Jacoby A, Cartwright A. Finding out about the views and experiences of maternity service users. In Garcia J, Kilpatrick R, Richards M, editors. The politics of maternity care. Services for women in twentieth-century Britain, Oxford: Clarendon Press; 1990. p.238-255.

69. Hollins Martin C, Fleming V. The birth satisfaction scale. Int J Health Care Qual Assur 2011;24:124-135. 


\section{Appendix I - Search Strategies}

\section{MEDLINE}

1 counsel\$.mp.

2 Cognitive Therapy/ or CBT.mp.

3 cognitive behavio?ral therapy.mp.

4 behavio $\$$ therapy.mp.

5 advice.mp

6 support.mp.

7 therap\$.mp.

8 advocacy.mp.

9 information.mp.

10 psycholog\$.mp.

11 psychiatr\$.mp

12 psychotherap\$.mp.

13 exp Relaxation/

14 psychosomatic.mp.

15 crisis oriented counse?ling.mp.

161 or 2 or 3 or 4 or 5 or 6 or 7 or 8 or 9 or 10 or 11 or 12 or 13 or 14 or 15

17 c?esar?an section.mp.

18 section c?esar?an.mp.

19 abdominal deliver\$.mp.

20 C?esar?an delivery.mp.

21 c section.mp.

2217 or 18 or 19 or 20 or 21

23 tokophobia.mp

24 tocophobia.mp.

25 parturiphobia.mp.

$26 \exp$ Fear/

27 exp Anxiety/

28 fear of childbirth.mp.

29 childbirth related anxiety.mp.

3023 or 24 or 25 or 26 or 27 or 28 or 29 

31 exp Pregnancy/
32 antenatal.mp.
33 ante natal.mp.
34 prenatal.mp.
35 pre natal.mp.
$36 \quad 31$ or 32 or 33 or 34 or 35
$37 \quad 16$ and 22 and 30 and 36

\section{EMBASE}

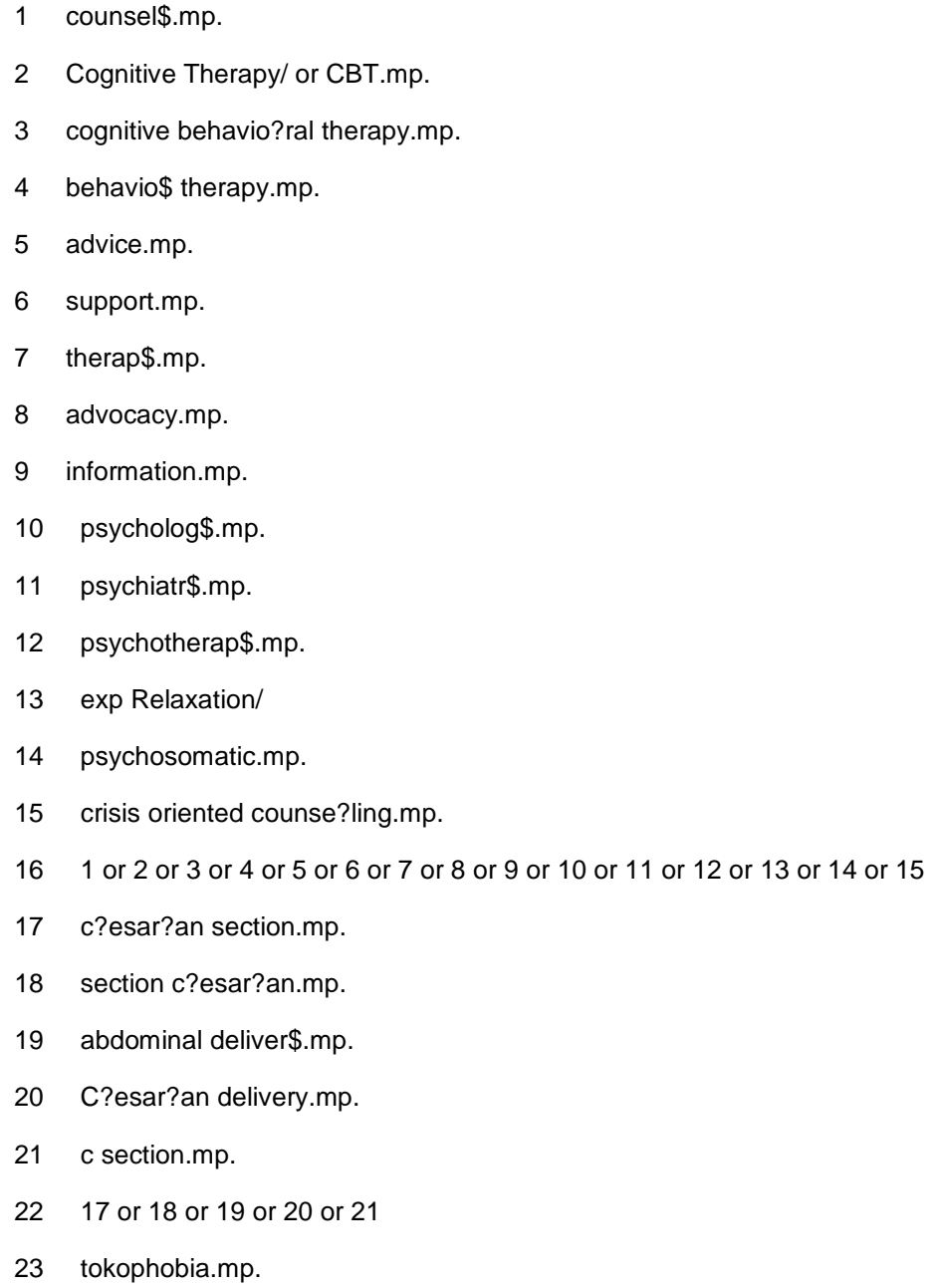




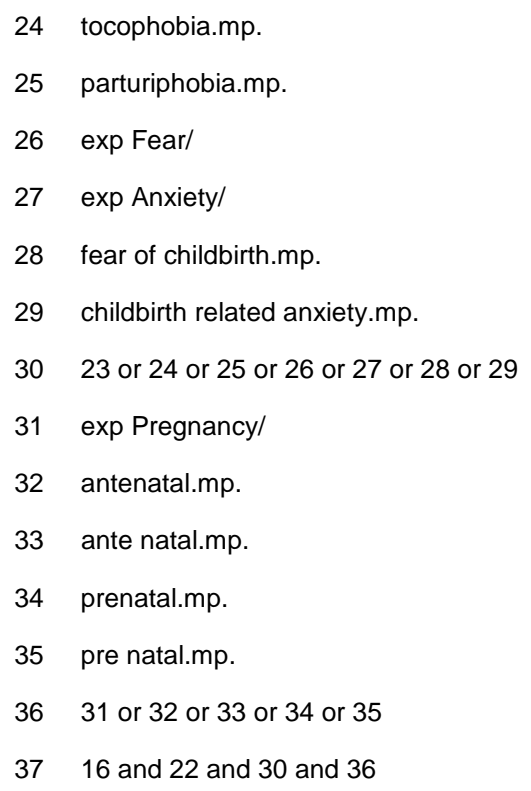

\section{The Cochrane Library}

1 counsel\$.mp.

2 Cognitive Therapy/ or CBT.mp.

3 cognitive behavio?ral therapy.mp.

4 behavio $\$$ therapy.mp.

5 advice.mp.

6 support.mp.

7 therap\$.mp.

8 advocacy.mp.

9 information.mp.

10 psycholog\$.mp.

11 psychiatr\$.mp.

12 psychotherap\$.mp.

13 exp Relaxation/

14 psychosomatic.mp

15 crisis oriented counse?ling.mp.

161 or 2 or 3 or 4 or 5 or 6 or 7 or 8 or 9 or 10 or 11 or 12 or 13 or 14 or 15 
17 c?esar?an section.mp.

18 section c?esar?an.mp.

19 abdominal deliver\$.mp.

20 C?esar?an delivery.mp.

21 c section.mp.

2217 or 18 or 19 or 20 or 21

23 tokophobia.mp.

24 tocophobia.mp.

25 parturiphobia.mp.

26 exp Fear/

27 exp Anxiety/

28 fear of childbirth.mp.

29 childbirth related anxiety. $\mathrm{mp}$.

3023 or 24 or 25 or 26 or 27 or 28 or 29

31 exp Pregnancy/

32 antenatal.mp.

33 ante natal.mp.

34 prenatal.mp.

35 pre natal.mp

$36 \quad 31$ or 32 or 33 or 34 or 35

$37 \quad 16$ and 22 and 30 and 36

\section{MIDIRS}

1 counsel\$.mp.

2 Cognitive Therapy/ or CBT.mp.

3 cognitive behavio?ral therapy.mp.

4 behavio $\$$ therapy.mp.

5 advice.mp.

6 support.mp.

7 therap\$.mp.

8 advocacy.mp.

9 information.mp. 


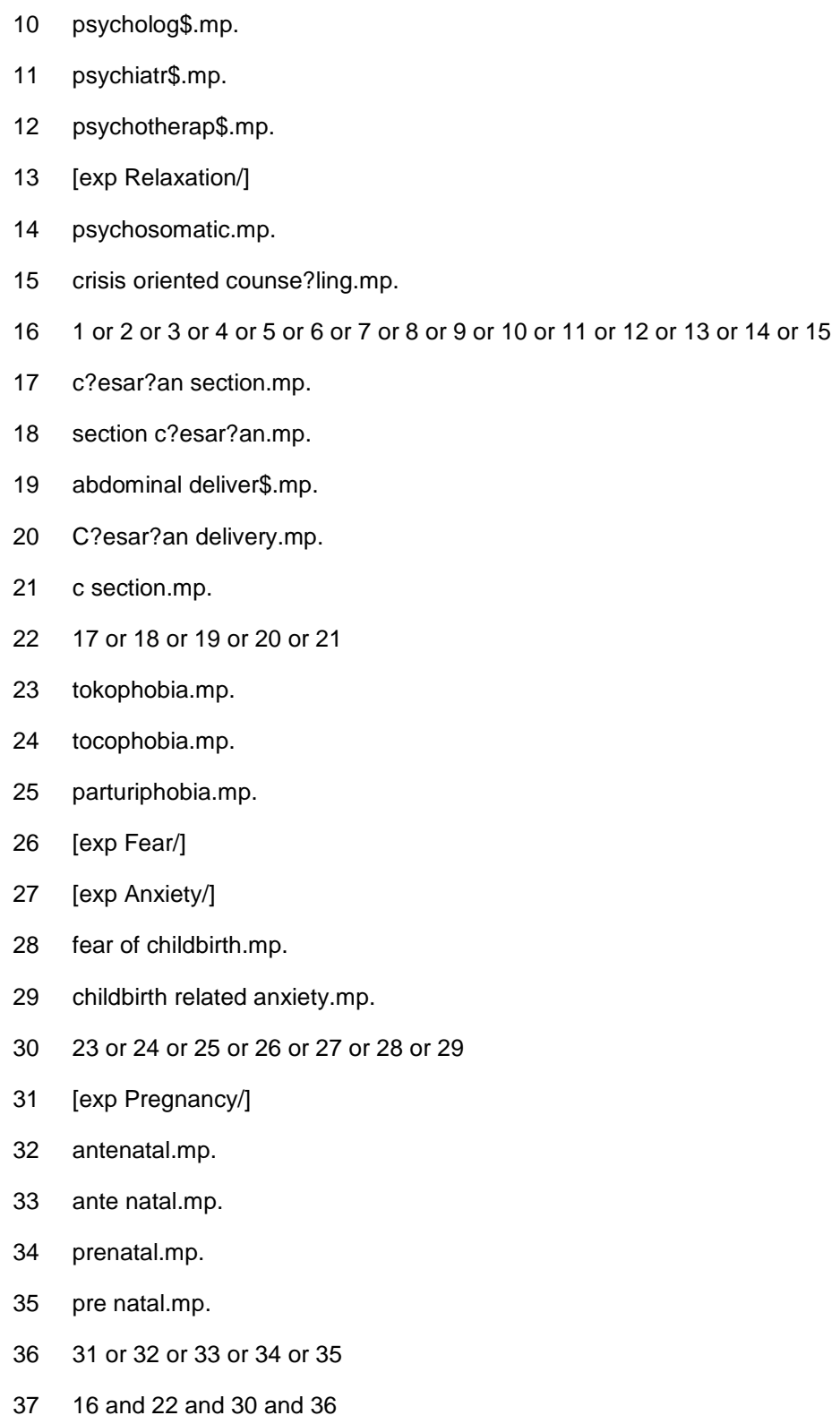

\section{CINAHL}

1 counsel* $^{*}$

2 CBT

3 cognitive behavio?ural therapy 


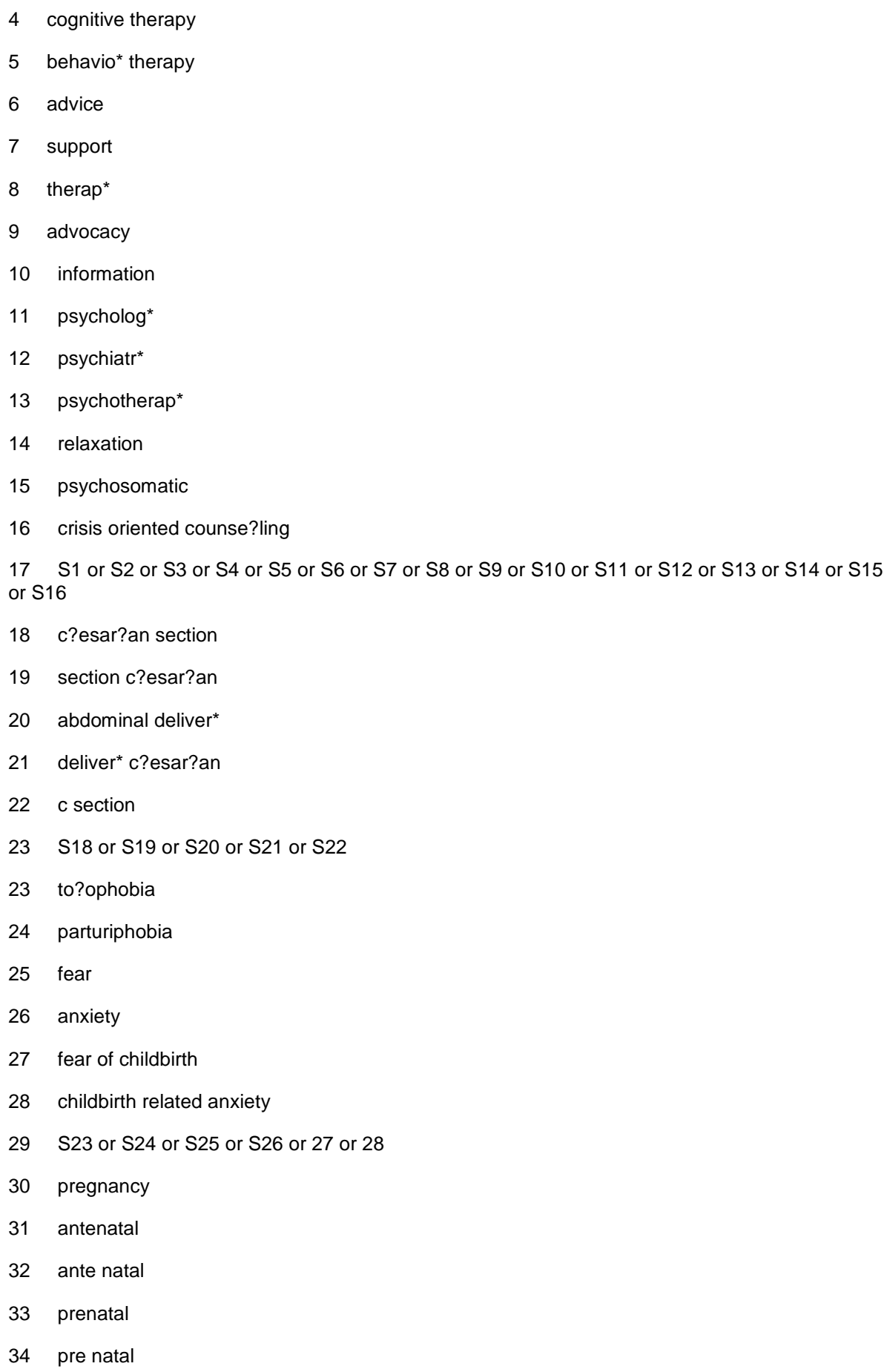


$35 \mathrm{~S} 30$ or $\mathrm{S} 31$ or S32 or S33 or S34

$5 \quad 17$ and 23 and 29 and 35

BNI

1 counsel\$.mp.

2 Cognitive Therapy/ or CBT.mp.

3 cognitive behavio?ral therapy.mp.

4 behavio\$ therapy.mp.

5 advice.mp.

6 support.mp.

7 therap\$.mp

8 advocacy.mp.

9 information.mp.

10 psycholog\$.mp.

11 psychiatr\$.mp.

12 psychotherap\$.mp.

13 exp Relaxation/

14 psychosomatic.mp.

15 crisis oriented counse?ling.mp.

161 or 2 or 3 or 4 or 5 or 6 or 7 or 8 or 9 or 10 or 11 or 12 or 13 or 14 or 15

17 c?esar?an section.mp.

18 section c?esar?an.mp.

19 abdominal deliver\$.mp.

20 C?esar?an delivery.mp.

21 c section.mp.

2217 or 18 or 19 or 20 or 21

23 tokophobia.mp

24 tocophobia.mp.

25 parturiphobia.mp

26 exp Fear/

27 exp Anxiety/

28 fear of childbirth.mp.

29 childbirth related anxiety.mp. 
3023 or 24 or 25 or 26 or 27 or 28 or 29

31 exp Pregnancy/

32 antenatal.mp.

33 ante natal.mp.

34 prenatal.mp.

35 pre natal.mp.

$36 \quad 31$ or 32 or 33 or 34 or 35

$37 \quad 16$ and 22 and 30 and 36

\section{PsycARTICLES}

1 counsel*

2 CBT

3 cognitive behavio?ural therapy

4 cognitive therapy

5 behavio* therapy

6 advice

7 support

8 therap*

9 advocacy

10 information

11 psycholog*

12 psychiatr*

13 psychotherap*

14 relaxation

15 psychosomatic

16 crisis oriented counse?ling

$17 \mathrm{~S} 1$ or S2 or S3 or S4 or S5 or S6 or S7 or S8 or S9 or S10 or S11 or S12 or S13 or S14 or S15 or S16

18 c?esar?an section

19 section c?esar?an

20 abdominal deliver ${ }^{\star}$

21 deliver* c?esar?an

22 c section

$23 \mathrm{~S} 18$ or $\mathrm{S} 19$ or $\mathrm{S} 20$ or $\mathrm{S} 21$ or $\mathrm{S} 22$ 
23 to?ophobia

24 parturiphobia

25 fear

26 anxiety

27 fear of childbirth

28 childbirth related anxiety

$29 \mathrm{~S} 23$ or S24 or S25 or S26 or 27 or 28

30 pregnancy

31 antenatal

32 ante natal

33 prenatal

34 pre natal

$35 \mathrm{~S} 30$ or S31 or S32 or S33 or S34

$5 \quad 17$ and 23 and 29 and 35

\section{MedNar}

1 (counsel* OR therap*)

2 c?esar?an

3 (to?ophobia OR "fear of childbirth")

$4 \quad 1$ and 2 and 3

ProQuest Dissertations and Theses.

1 (counsel* OR therap*)

2 c?esar?an

3 (to?ophobia OR "fear of childbirth")

$4 \quad 1$ and 2 and 3 


\section{Appendix II - Appraisal instruments}

MAStARI Appraisal instruments

JBI Critical Appraisal Checklist for Randomised Control / Pseudo-randomised Trial

\begin{tabular}{|c|c|c|c|c|}
\hline \multirow[t]{2}{*}{ Author } & \multirow{2}{*}{$\begin{array}{l}\text { - Yea } \\
\text { Yes }\end{array}$} & \multicolumn{3}{|c|}{ _ Record Number } \\
\hline & & No & Unclear & Not Applicable \\
\hline $\begin{array}{l}\text { 1. Was the assignment to treatment } \\
\text { groups truly random? }\end{array}$ & $\square$ & $\square$ & $\square$ & $\square$ \\
\hline $\begin{array}{l}\text { 2. Were participants blinded to } \\
\text { treatment allocation? }\end{array}$ & $\square$ & $\square$ & $\square$ & $\square$ \\
\hline $\begin{array}{l}\text { 3. Was allocation to treatment groups } \\
\text { concealed from the allocator? }\end{array}$ & $\square$ & $\square$ & $\square$ & $\square$ \\
\hline $\begin{array}{l}\text { 4. Were the outcomes of people who } \\
\text { withdrew described and included in } \\
\text { the analysis? }\end{array}$ & $\square$ & $\square$ & $\square$ & $\square$ \\
\hline $\begin{array}{l}\text { 5. Were those assessing outcomes } \\
\text { blind to the treatment allocation? }\end{array}$ & $\square$ & $\square$ & $\square$ & $\square$ \\
\hline $\begin{array}{l}\text { 6. Were the control and treatment } \\
\text { groups comparable at entry? }\end{array}$ & $\square$ & $\square$ & $\square$ & $\square$ \\
\hline $\begin{array}{l}\text { 7. Were groups treated identically } \\
\text { other than for the named } \\
\text { interventions }\end{array}$ & $\square$ & $\square$ & $\square$ & $\square$ \\
\hline $\begin{array}{l}\text { 8. Were outcomes measured in the } \\
\text { same way for all groups? }\end{array}$ & $\square$ & $\square$ & $\square$ & $\square$ \\
\hline $\begin{array}{l}\text { 9. Were outcomes measured in a } \\
\text { reliable way? }\end{array}$ & $\square$ & $\square$ & $\square$ & $\square$ \\
\hline \multirow{2}{*}{$\begin{array}{l}\text { 10. Was appropriate statistical analysis } \\
\text { used? }\end{array}$} & $\square$ & $\square$ & $\square$ & $\square$ \\
\hline & $\square$ & $\square$ & $\square$ & $\square$ \\
\hline Overall appraisal: & & $\square$ & & further ir \\
\hline
\end{tabular}

Comments (Including reason for exclusion) 


\section{JBI Critical Appraisal Checklist for Comparable Cohort/ Case Control}

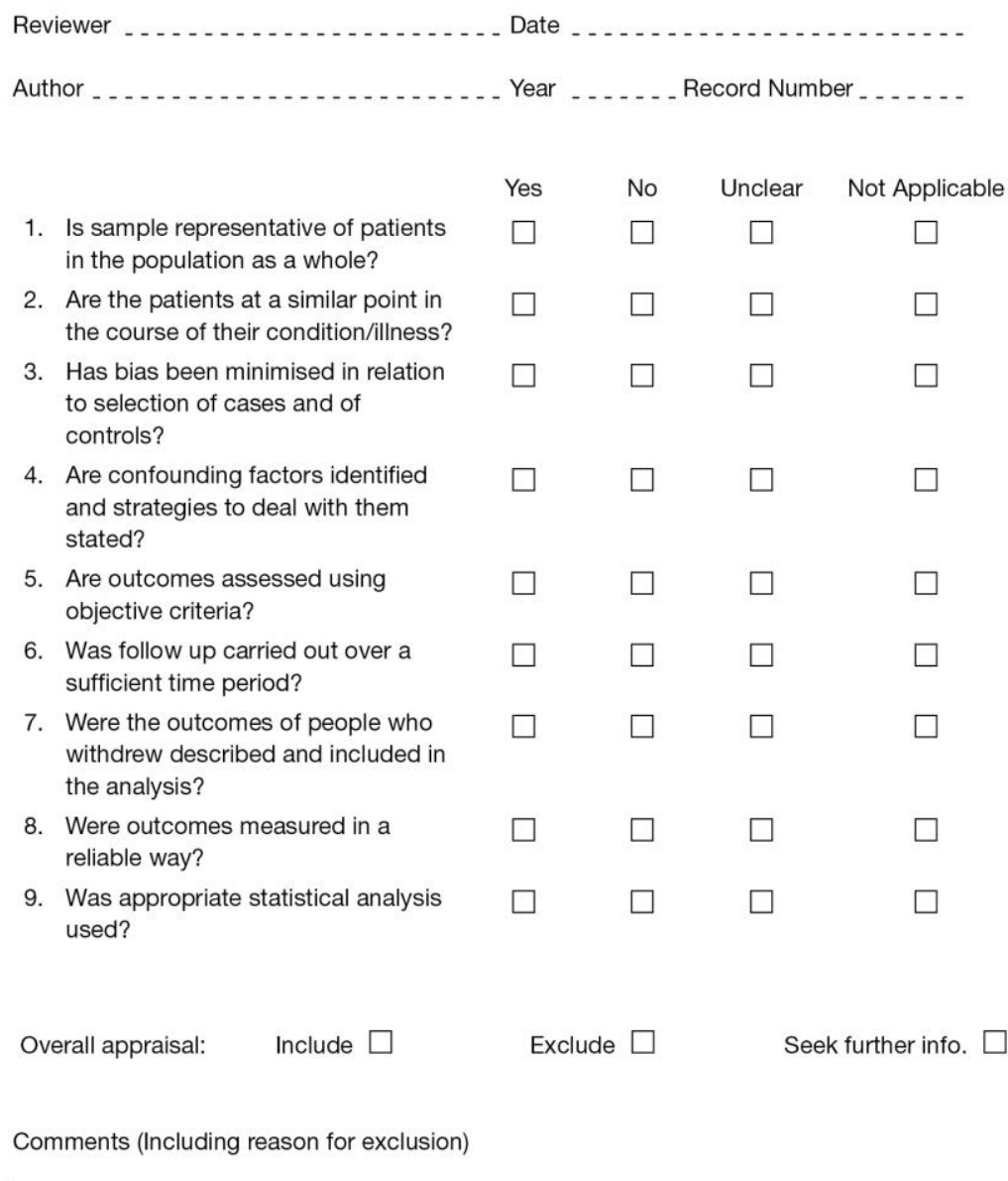




\section{JBI Critical Appraisal Checklist for Descriptive / Case Series}

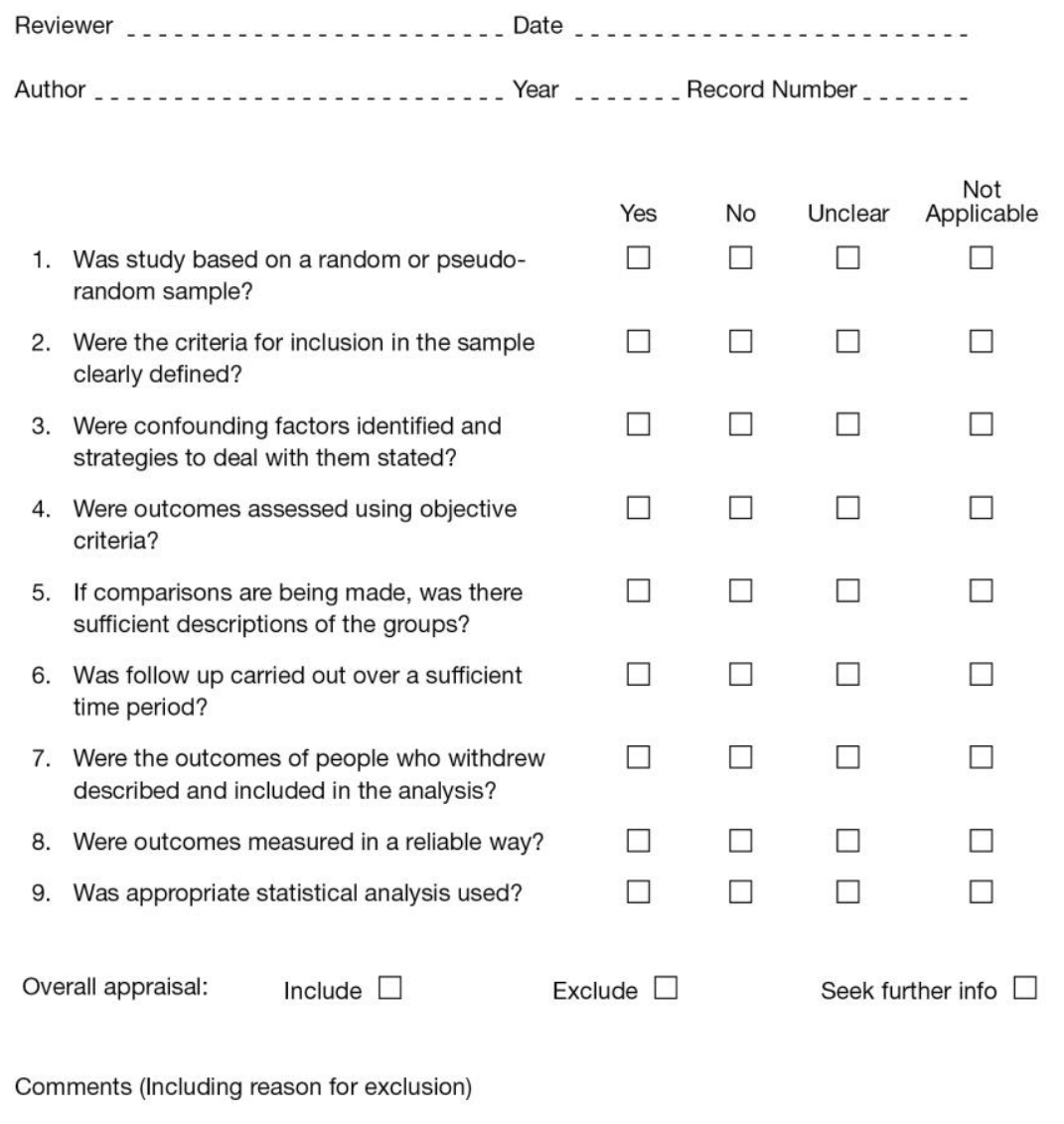




\section{Appendix III - Data extraction instruments}

MAStARI data extraction instrument

\section{JBI Data Extraction Form for \\ Experimental / Observational Studies}

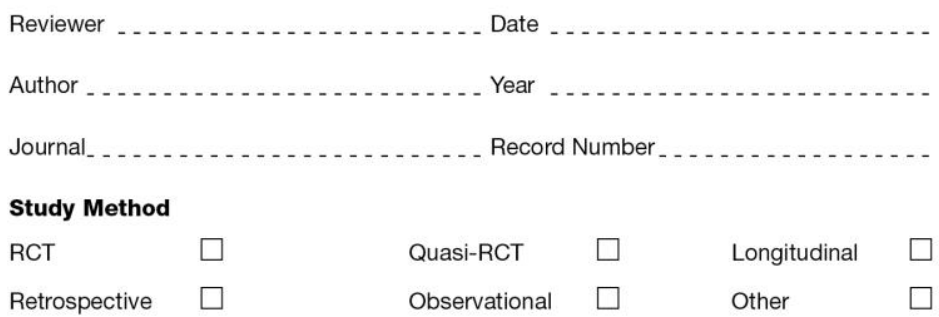

Participants

Setting

Population

Sample size

Group A

Group B

Interventions

Intervention A

Intervention B

Authors Conclusions:

Reviewers Conclusions: 
Study results

Dichotomous data

\begin{tabular}{|l|l|l|}
\hline Outcome & $\begin{array}{c}\text { Intervention ( ) } \\
\text { number/total number }\end{array}$ & $\begin{array}{c}\text { Intervention ( ) } \\
\text { number/total number }\end{array}$ \\
\hline & & \\
\hline & & \\
\hline & & \\
\hline & & \\
\hline
\end{tabular}

Continuous data

\begin{tabular}{|l|l|l|}
\hline Outcome & $\begin{array}{c}\text { Intervention ( ) } \\
\text { number/total number }\end{array}$ & $\begin{array}{c}\text { Intervention ( ) } \\
\text { number/total number }\end{array}$ \\
\hline & & \\
\hline & & \\
\hline & & \\
\hline & & \\
\hline & & \\
\hline
\end{tabular}




\section{Appendix IV - Excluded Studies}

\section{Excluded at critical appraisal}

Ryding EL. Investigation of 33 women who demanded a caesarean section for personal reasons. Acta Obstet Gyn Scan. 1993;72:280-285.

Reason for exclusion: The study set out to determine why CS was demanded, so no pre-determined definition for tokophobia was given. The study lacks clarity over whether confounding factors were identified. There are no details of how interviews were conducted and how data were managed or recorded. There are no clear tables of interventions related to outcomes and numbers seem not to add up. For example, women appeared to have one of three interventions: counselling, crisis intervention or short-term psychotherapy. The paper states that of the 33 women studied, 21 received counselling (the paper later gives this figure as 19), but elsewhere it says that nine women chose therapy and two chose crisis intervention. This appears to leave one women unaccounted for. The number of women followed up postnatally is also unclear and there is no indication of why some women were not followed up. It is unclear how mental wellbeing was assessed post-delivery or who made the assessment. However this was a useful background study as it helped to crystallise some of the issues as a basis for further work.

\section{Excluded at review of full texts}

Bastani F, Hidarnia A, Montgomery KS, Aguilar-Vafaei ME, Kazemnejad A. Does relaxation education in anxious primigravid Iranian women influence adverse pregnancy outcomes? J Perinat Neonat Nurs. 2006;20(2):138-146.

Reason for exclusion: Outcomes mainly relate to child. Definition for tokophobia inadequate - 'high anxiety level' measured by Spielberger's State-Trait Anxiety Inventory / anxiety- and stress-related issues in pregnancy - not necessarily pregnancy-related!

Dunkley-Bent J.A consultant midwife's community clinic. Br J Midwifery. 2004;12(3):144-171.

Reason for exclusion: Addresses outcomes of women with FOC, support offered and outcomes for maternal requests of CS in a consultant midwife's community clinic, but it is unclear whether the samples consisted of the same populations. Not enough evidence given.

Khunpradit S, Tavender E, Lumbiganon P, Laopaiboon M, Wasiak J, Gruen RL. Non-clinical interventions for reducing unnecessary caesarean section (review). Cochrane Database Syst Rev 2011, Issue 6. Art. No.: CD005528. DOI: 10.1002/14651858.CD005528.pub2.

Reason for exclusion: Focus is not on FOC (interventions for CS only), but useful to develop search strategy.

Melender $\mathrm{H}-\mathrm{L}$. Fears and coping strategies associated with pregnancy and childbirth in Finland. J Midwifery Womens Health. 2002;47(4):256-263.

Reason for exclusion: Health care workers (HCWs) not immediately involved in the research process, but recollection of birth experience included various HCWs, e.g. community health nurses, midwives, physicians, psychologists. Specific interventions not mentioned in any depth, although discussions between women and HCWs found to be helpful and 'use of healthcare services' included as one example of dispelling/alleviating FOC, e.g. visits to maternity health/high-risk clinics, childbirth education. 
Otley $\mathrm{H}$. Fear of childbirth: understanding the causes, impact and treatment. $\mathrm{Br} \mathrm{J}$ Midwifery. $2011 ; 19(4): 21-26$.

Reason for exclusion: Narrative paper. Interesting discussion about intervention techniques used in other studies.

Sapountzi-Krepia D, Tsaloglidou A, Psychogiou M, Lazaridou C, Vehvilainen Julkunen K. Mothers' experiences of pregnancy, labour and childbirth: A qualitative study in Northern Greece.Int J Nurs Prac. 2011;17(6):583-90.

Reason for exclusion: FOC not discussed.

Serçekuş P \& Mete S. Turkish women's perceptions of antenatal education. Int Nurs Rev. 2010;57:395-401.

Reason for exclusion: FOC not included as a variable. Focus on post-birth.

Thomson GM \& Downe S. Changing the future to change the past: women's experiences of a positive birth following a traumatic birth experience. J Reprod Infant Psychol. 2006;28(1):102-112.

Reason for exclusion: CS demand not discussed with regard to previous traumatic birth experience. CS involved in both positive and traumatic birth experiences. Specific counselling techniques to reduce CS or FOC not a focus, but discussions with consultant midwives highlighted as a positive experience. Neither FOC nor tokophobia specifically defined.

Tschudin S, Alder J, Hendriksen S, Bitzer J, Popp KA, Zanetti R, Hösli I, Holzgreve W, Geissbühler V. Previous birth experience and birth anxiety: predictors of caesarean section on demand? Journal of Psychosom Obstet Gynecol. 2009;30(3):175-180.

Reason for exclusion: No intervention (RCT exploring effectiveness of psychological intervention discussed, but author correspondence suggested that this study did not reach completion). Main issue was predictors of CS. 


\section{Appendix V - Summary of studies included in the review}

\begin{tabular}{|c|c|c|c|c|c|c|}
\hline $\begin{array}{l}\text { Author/s } \\
\text { Year and } \\
\text { Country }\end{array}$ & Date & $\begin{array}{l}\text { Aims / Research } \\
\text { Question }\end{array}$ & Sample & $\begin{array}{l}\text { Design and Data } \\
\text { collection } \\
\text { methods }\end{array}$ & Results & Authors' Conclusions \\
\hline $\begin{array}{l}\text { Sjögren and } \\
\text { Thomassen }^{15}\end{array}$ & 1997 & $\begin{array}{l}\text { To follow up women who } \\
\text { had received } \\
\text { individualised } \\
\text { psychological/obstetric } \\
\text { support because of } \\
\text { anxiety and to describe } \\
\text { this model of support }\end{array}$ & $\begin{array}{l}100 \text { women who had } \\
\text { suffered from anxiety } \\
\text { of delivery and referred } \\
\text { to psychosomatic } \\
\text { outpatient clinic for } \\
\text { individualised } \\
\text { psychological/obstetric } \\
\text { support compared with } \\
100 \text { matched } \\
\text { references from } \\
\text { delivery register }\end{array}$ & $\begin{array}{l}\text { Case control: } \\
\text { Review of clinical } \\
\text { records }\end{array}$ & $\begin{array}{l}\text { Women in study group had higher } \\
\text { frequency of psychic problems. } \\
\\
68 \text { study group women initially requested } \\
\text { Caesarean section (CS). After } \\
\text { individualised psychological/obstetric } \\
\text { support } 38 \text { agreed to vaginal delivery. }\end{array}$ & $\begin{array}{l}\text { Psychosomatic support for } \\
\text { women with severe fear of } \\
\text { delivery resulted in } 50 \% \text { reduction } \\
\text { for CS for psychosocial } \\
\text { indications and vaginal deliveries } \\
\text { similar to the reference group. }\end{array}$ \\
\hline $\begin{array}{l}\text { Sjögren }{ }^{55} \\
\text { Sweden }\end{array}$ & 1998 & & $\begin{array}{l}72 \text { matched pairs } \\
\text { provided answers }\end{array}$ & $\begin{array}{l}\text { Case control: } \\
\text { Questionnaires } \\
\text { sent to women } 1 \\
\text { to } 3 \text { years } \\
\text { following birth }\end{array}$ & $\begin{array}{l}\text { The delivery experience was similar in } \\
\text { both groups, study group in some } \\
\text { respects more positive. Women who had } \\
\text { initially wished for CS but eventually } \\
\text { underwent vaginal birth, were as satisfied } \\
\text { as those who had not wished a CS. } \\
\\
\text { Women recommended that staff take } \\
\text { women's worries seriously, while giving } \\
\text { support and building up trust. }\end{array}$ & $\begin{array}{l}\text { Women remembered the delivery } \\
\text { similarly as reference group. } \\
\text { Women who initially requested a } \\
\text { CS seemed satisfied with delivery } \\
\text { The cost for support to all women } \\
\text { was lower than the cost saving by } \\
\text { the lower rate of CS for } \\
\text { psychological indication. }\end{array}$ \\
\hline $\begin{array}{l}\text { Saisto et al. }{ }^{21} \\
\text { Finland }\end{array}$ & 2001 & $\begin{array}{l}\text { To compare intensive } \\
\text { and conventional } \\
\text { therapy for severe fear } \\
\text { of childbirth }\end{array}$ & $\begin{array}{l}176 \text { women with fear of } \\
\text { childbirth were } \\
\text { randomly assigned at } \\
26 \text { weeks of pregnancy } \\
\text { to receive either } \\
\text { intensive therapy or } \\
\text { conventional }\end{array}$ & $\begin{array}{l}\text { RCT: } \\
\text { Completed } 3 \\
\text { Questionnaires: } \\
\text { 1. Prior to } \\
\text { randomisation } \\
\text { 2. } 4 \text { weeks before } \\
\text { due date } \\
\text { 3. } 3 \text { months } \\
\text { postpartum }\end{array}$ & $\begin{array}{l}\text { Birth related concerns reduced in the } \\
\text { intensive therapy group but increased in } \\
\text { conventional therapy group }(\mathrm{P}=0.022) \\
62 \% \text { of those originally requesting a CS, } \\
\text { chose to give birth vaginally, this was } \\
\text { equal for both groups. } \\
\\
\text { There was no difference between either } \\
\text { group with regards satisfaction with } \\
\text { childbirth or puerperal depression }\end{array}$ & $\begin{array}{l}\text { Both therapies reduced the } \\
\text { number of CS, this was more } \\
\text { evident in nulliparous and well- } \\
\text { motivated women. Pregnancy and } \\
\text { birth related anxieties and } \\
\text { concerns were reduced in the } \\
\text { intensive therapy group, and } \\
\text { labours were shorter. }\end{array}$ \\
\hline
\end{tabular}




\begin{tabular}{|c|c|c|c|c|c|c|}
\hline $\begin{array}{l}\text { Ryding et } \\
\text { al. }{ }^{57} \\
\text { Sweden }\end{array}$ & 2003 & $\begin{array}{l}\text { Was the delivery } \\
\text { experience of women } \\
\text { counselled by midwives } \\
\text { for FOC as good as or } \\
\text { more negative / } \\
\text { frightening than the } \\
\text { experience of the } \\
\text { average parturient? } \\
\text { Did the women } \\
\text { counselled by midwives } \\
\text { for FOC report the same } \\
\text { or a higher prevalence } \\
\text { and frequency of } \\
\text { symptoms of PTSD after } \\
\text { childbirth compared with } \\
\text { the average parturient? } \\
\text { Were the women who } \\
\text { asked for help because } \\
\text { of FOC satisfied with the } \\
\text { care provided? } \\
\text { Was the CS rate of the } \\
\text { women counselled by } \\
\text { midwives for FOC } \\
\text { similar to or higher than } \\
\text { the overall CS rate in the } \\
\text { hospital? }\end{array}$ & $\begin{array}{l}53 \text { women who } \\
\text { consulted midwives in } \\
\text { the FOC team } \\
\text { compared with } 53 \\
\text { women matched for } \\
\text { parity and mode of } \\
\text { birth }\end{array}$ & $\begin{array}{l}\text { Case control: } \\
\text { All women } \\
\text { completed } 2 \\
\text { questionnaires } \\
\text { (W-DEQ) and } \\
\text { (IES) } 1-14 \\
\text { months } \\
\text { postpartum }\end{array}$ & $\begin{array}{l}\text { Most women (both groups) reported } \\
\text { overall satisfaction with care given during } \\
\text { the antenatal period and during and after } \\
\text { birth. } \\
\text { Women treated by the FOC team reported } \\
\text { a higher degree of frightening experience } \\
\text { of birth and more frequent symptoms of } \\
\text { post-traumatic stress related to birth than } \\
\text { the comparison group. } \\
\text { CS rate in the study group was } 26 \% \text {, } \\
\text { compared with an } 11 \% \text { CS rate within the } \\
\text { department. } \\
\text { Of the } 20 \text { women who asked for CS at } \\
\text { initial contact with the FOC team, } 11 \\
\text { underwent CS ( } 8 \text { elective and } 3 \\
\text { emergency) }\end{array}$ & $\begin{array}{l}\text { Women in the study group } \\
\text { reported less positive experiences } \\
\text { of birth than the average } \\
\text { parturient in the unit, highlighting } \\
\text { the need for more effective } \\
\text { treatment. However, as most } \\
\text { women were satisfied with their } \\
\text { care and the outcome of the birth, } \\
\text { counselling from the FOC team } \\
\text { may have helped improve the } \\
\text { situation to some degree. }\end{array}$ \\
\hline $\begin{array}{l}\text { Saisto et al. }{ }^{58} \\
\text { Finland }\end{array}$ & 2006 & $\begin{array}{l}\text { Therapeutic group } \\
\text { psychoeducation and } \\
\text { relaxation in treating } \\
\text { FOC }\end{array}$ & $\begin{array}{l}102 \text { nulliparous women } \\
\text { referred for } \\
\text { consultation with a } \\
\text { psychologist because } \\
\text { FOC. These women } \\
\text { agreed to join } \\
\text { therapeutic group } \\
\text { sessions with } \\
\text { relaxation exercises }\end{array}$ & $\begin{array}{l}\text { Case control: } \\
\text { Questionnaire at } \\
\text { enrolment to } \\
\text { study (modified } \\
\text { Areskog } \\
\text { questionnaire) }\end{array}$ & $\begin{array}{l}\text { Prior to group sessions experimental } \\
\text { group and conventional group had similar } \\
\text { FOC scores (rated one to ten, ten being } \\
\text { greatest fear). EG } 6.9 \pm 2.0 \text { (SD) } \\
\text { CG } 6.0 \pm 1.6 \text { (SD) } \\
12.7 \% \text { of women in EG had CS for FOC } \\
\text { which differed significantly when }\end{array}$ & $\begin{array}{l}\text { Significantly more requests for CS } \\
\text { for FOC were withdrawn in the } \\
\text { EG than in CG following sessions. } \\
\text { Group psychoeducation and } \\
\text { relaxation exercises were well } \\
\text { received and rated as very helpful }\end{array}$ \\
\hline
\end{tabular}




\begin{tabular}{|c|c|c|c|c|c|c|}
\hline & & & $\begin{array}{l}\text { (Experimental Group - } \\
\text { EG). } \\
\text { This group was } \\
\text { compared with } 85 \\
\text { women given } \\
\text { conventional treatment } \\
\text { for FOC (two } \\
\text { appointments with an } \\
\text { obstetrician } \\
\text { (Conventional Group - } \\
\text { CG) }\end{array}$ & $\begin{array}{l}\text { Data gathered } \\
\text { from maternity } \\
\text { records } \\
\text { Experimental } \\
\text { group rated group } \\
\text { therapy sessions } \\
\text { with anonymous } \\
\text { feedback form. }\end{array}$ & $\begin{array}{l}\text { compared with women in CG } 22.4 \%(p=- \\
0.02) \\
\text { Women in EG rated helpfulness of } \\
\text { sessions as } 8.5 \pm 1.6 \text {. Sharing of feelings } \\
\text { was mentioned twice as often as receiving } \\
\text { of information as the most helpful factor in } \\
\text { relieving fear. }\end{array}$ & \\
\hline $\begin{array}{l}\text { Waldenström } \\
\text { et al.40 } \\
\text { Sweden }\end{array}$ & 2006 & $\begin{array}{l}\text { To investigate the } \\
\text { prevalence of FOC in a } \\
\text { nationwide sample and } \\
\text { its association with } \\
\text { subsequent rates of CS } \\
\text { and overall childbirth } \\
\text { experience. }\end{array}$ & $\begin{array}{l}\text { Women recruited at } \\
\text { their first antenatal } \\
\text { visit. } \\
290 \text { women who } \\
\text { expressed very } \\
\text { negative feelings about } \\
\text { birth in 2nd trimester } \\
\text { and/or who received } \\
\text { counselling } \\
\text { Reference group - } \\
2372 \text { women who } \\
\text { experienced no } \\
\text { negative feelings or } \\
\text { counselling }\end{array}$ & $\begin{array}{l}\text { Case control: } \\
\text { Postal } \\
\text { questionnaires at } \\
16 \text { weeks and } 2 \\
\text { months postnatal } \\
\text { Maternal worry } \\
\text { was measured by } \\
\text { Swedish version } \\
\text { of Cambridge } \\
\text { Worry Scale. } \\
\text { Depressive } \\
\text { symptoms were } \\
\text { measured by } \\
\text { Edinburgh } \\
\text { Postnatal } \\
\text { Depression Scale. }\end{array}$ & $\begin{array}{l}\text { Women who underwent counselling for } \\
\text { FOC had higher rates of CS but not } \\
\text { higher rates of negative childbirth } \\
\text { experience. Very negative feelings without } \\
\text { counselling was not related with increased } \\
\text { CS rates but was with an increased } \\
\text { reporting of a negative birth experience. }\end{array}$ & $\begin{array}{l}\text { Although FOC combined with } \\
\text { counselling may increase the rate } \\
\text { of CS, FOC without counselling } \\
\text { may have a negative impact on } \\
\text { the childbirth experience }\end{array}$ \\
\hline $\begin{array}{l}\text { Nerum -et } \\
\text { al. }{ }^{31} \\
\text { Norway }\end{array}$ & 2006 & $\begin{array}{l}\text { To describe the } \\
\text { intervention, the } \\
\text { women's psychosocial } \\
\text { problems in relation to } \\
\text { degree of fear of birth, } \\
\text { changes in their wishes } \\
\text { for mode of birth and } \\
\text { birth outcome, women's }\end{array}$ & $\begin{array}{l}86 \text { pregnant women } \\
\text { with fear of birth and a } \\
\text { request for CS, who } \\
\text { were referred for crisis- } \\
\text { oriented counselling by } \\
\text { a psychosocial team }\end{array}$ & $\begin{array}{l}\text { Case series: } \\
\text { Data gathered } \\
\text { from: referral } \\
\text { letters, maternity } \\
\text { care records and } \\
\text { follow-up survey } \\
\text { 2-4 years after } \\
\text { birth }\end{array}$ & $\begin{array}{l}\text { Following the intervention, } 86 \% \text { changed } \\
\text { their original request for CS. } \\
\text { Follow-up survey confirmed long term } \\
\text { satisfaction with having changed their } \\
\text { request and were satisfied with the } \\
\text { counselling } 2 \text { to } 4 \text { years later. }\end{array}$ & $\begin{array}{l}\text { Impending birth can activate } \\
\text { previous traumatic experiences, } \\
\text { abuse and psychiatric disorders } \\
\text { that may give rise to a fear of } \\
\text { vaginal birth. } \\
\\
\text { Women who were referred for } \\
\text { specialist counselling with a fear }\end{array}$ \\
\hline
\end{tabular}




\begin{tabular}{|c|c|c|c|c|c|c|}
\hline & & $\begin{array}{l}\text { satisfaction with } \\
\text { intervention and their } \\
\text { wishes for future births. }\end{array}$ & $\begin{array}{l}\text { Fear of birth was } \\
\text { accompanied by } \\
\text { extensive psychosocial } \\
\text { problems in most } \\
\text { women: } \\
89.5 \% \text { experienced } \\
\text { previous anxiety and / } \\
\text { or depression } \\
25.6 \% \text { had received } \\
\text { prior treatment for } \\
\text { psychiatric disorders } \\
43.3 \% \text { had an eating } \\
\text { disorder } \\
63.1 \% \text { had been } \\
\text { subjected to some } \\
\text { form of abuse }\end{array}$ & & & $\begin{array}{l}\text { of birth and a consequent request } \\
\text { for CS were able to work through } \\
\text { their causes of this fear and } \\
\text { change their request to a vaginal } \\
\text { birth. Longer term follow-up } \\
\text { showed they remained pleased } \\
\text { with their choice. }\end{array}$ \\
\hline $\begin{array}{l}\text { Halvorsen et } \\
\text { al. }{ }^{56} \\
\text { Norway }\end{array}$ & 2010 & $\begin{array}{l}\text { 1. What are the } \\
\text { predictors of change in a } \\
\text { wish for CS and for } \\
\text { vaginal birth in women } \\
\text { who fear birth? } \\
\text { 2. Does a change from } \\
\text { 'autonomy attitude' to a } \\
\text { 'coping attitude' increase } \\
\text { the number of women } \\
\text { who change their } \\
\text { request for a CS and } \\
\text { who give birth vaginally? }\end{array}$ & $\begin{array}{l}\text { All women } \\
\text { consecutively referred } \\
\text { to the antenatal clinic } \\
\text { with fear of birth and } \\
\text { accompanying request } \\
\text { for a CS, received } \\
\text { crisis-oriented } \\
\text { counselling. } \\
\text { Sample } 1 \text { (2000-2002 } \\
\text { Nerum et al 2006) } \\
86 \text { women: } \\
43 \text { counselled by } \\
\text { Midwife A, who } \\
\text { conveyed a 'coping' } \\
\text { attitude and approach. } \\
43 \text { counselled by } \\
\text { Midwife B who } \\
\text { conveyed an } \\
\text { 'autonomy' attitude and } \\
\text { approach. }\end{array}$ & $\begin{array}{l}\text { Case series: } \\
\text { Data gathered } \\
\text { from: referral } \\
\text { letters, } \\
\text { counselling and } \\
\text { maternity care } \\
\text { records }\end{array}$ & $\begin{array}{l}\text { Sample 1: } 95 \% \text { of women counselled by } \\
\text { Midwife A with a 'coping' attitude changed } \\
\text { their initial request for CS. } 77 \% \text { of women } \\
\text { counselled by a Midwife B with an } \\
\text { 'autonomy' attitude changed their request. } \\
\text { Sample 2: Both Midwife A and Midwife B } \\
\text { counselled using a 'coping' attitude. } 97 \% \\
\text { (A) and } 93 \% \text { (B) of women changed their } \\
\text { desire for CS }\end{array}$ & $\begin{array}{l}\text { A 'coping' attitude by the } \\
\text { counsellor was strongly } \\
\text { associated with a change of } \\
\text { request for CS to giving birth } \\
\text { vaginally by women seen in the } \\
\text { antenatal clinic. } \\
\text { A 'coping' attitude can be learned } \\
\text { through critical reflection and } \\
\text { awareness of the counsellor's } \\
\text { attitude with quantifiable clinical } \\
\text { results. }\end{array}$ \\
\hline
\end{tabular}




\begin{tabular}{|c|c|c|c|c|c|c|}
\hline & & & $\begin{array}{l}\text { Sample } 2 \text { (2004-2006) } \\
107 \text { women: } \\
63 \text { counselled by } \\
\text { Midwife A } \\
44 \text { counselled by } \\
\text { Midwife B; both } \\
\text { counsellors conveyed } \\
\text { a 'coping' attitude and } \\
\text { approach }\end{array}$ & & & \\
\hline $\begin{array}{l}\text { Sydsjö et } \\
\text { al. }{ }^{59} \\
\text { Sweden }\end{array}$ & 2012 & $\begin{array}{l}\text { To compare obstetric } \\
\text { outcomes for women } \\
\text { with FOC who received } \\
\text { counselling during } \\
\text { pregnancy with women } \\
\text { without FOC }\end{array}$ & $\begin{array}{l}353 \text { women who were } \\
\text { referred to a } \\
\text { psychosocial; } \\
\text { obstetrics and } \\
\text { gynaecology unit with } \\
\text { FOC (Index group-IG) } \\
\text { were compared with } \\
579 \text { women without } \\
\text { fear (Reference Group } \\
\text { - RG) }\end{array}$ & $\begin{array}{l}\text { Case control: } \\
\text { Delivery data }\end{array}$ & $\begin{array}{l}\text { Elective CS was more common in IG } \\
(\mathrm{p}<0.001) \text {, as well as this, women with } \\
\text { FOC who were scheduled for vaginal birth } \\
\text { had a higher rate of emergency CS } \\
(\mathrm{p}=0.007) \\
\text { Elective CS was more common in parous } \\
\text { women with FOC, whereas instrumental } \\
\text { delivery was more common in nullips with } \\
\text { FOC } \\
\text { There were no differences between either } \\
\text { group with regards complications in } \\
\text { pregnancy, delivery or during the } \\
\text { postpartum period. }\end{array}$ & $\begin{array}{l}\text { Even following psychological } \\
\text { counselling, FOC appears to be a } \\
\text { predisposing factor for elective } \\
\text { and emergency CS. } \\
\text { Great effort to support women } \\
\text { with FOC is necessary so as to } \\
\text { avoid traumatising births and } \\
\text { negative experiences, particularly } \\
\text { for women having their first baby }\end{array}$ \\
\hline
\end{tabular}




\section{Appendix VI - Definitions/ diagnosis of tokophobia}

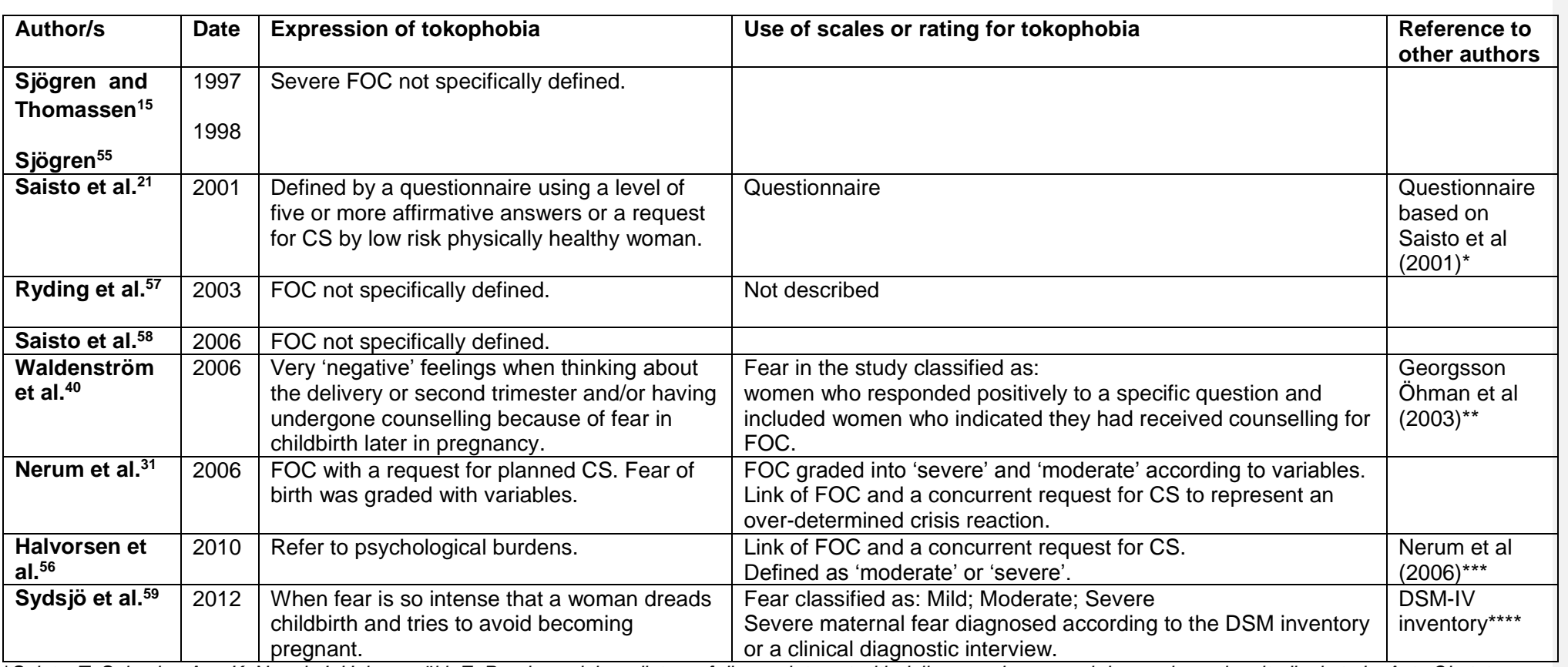

`Saisto, T. Salmela -Ara, K. Nurmi, J. Halmesmäki, E. Psychosocial predictors of disappointment with delivery and puerperal depression: a longitudinal study. Acta Obstet Gynaecol Scand. $2001 ; 80: 39-45$

** Georgsson Öhman S, Grunewald C, Waldenström U. Women's worries during pregnancy: testing the Cambridge Worry Scale on 200 Swedish women. Scand J Caring Sci. 2003; 17: 148-152

${ }^{\star * \star}$ Nerum H, Halvorsen L, Sørlie Tand Øian P - Maternal Request for Cesarean Section due to fear of birth: Can it be changed through crisis -oriented counselling? Birth. 2006; 33: 221-228

${ }^{* * * *}$ American Psychological Association. Diagnostic and statistical manual of mental disorders. 4th edition. Washington, D.C.: APA; 1994.

CS=caesarean section; FOC= Fear of childbirth 


\section{Appendix VII - Participants}

\begin{tabular}{|c|c|c|c|c|c|}
\hline Author/s & Date & Intervention group & Comparison & Excluded & Comments \\
\hline Saisto et al. ${ }^{21}$ & 2001 & $\begin{array}{l}85 \text { Low risk and physically healthy } \\
\text { women referred for antenatal } \\
\text { consultation because of fear of vaginal } \\
\text { delivery as diagnosed by questionnaire. }\end{array}$ & $\begin{array}{l}91 \text { low risk and physically healthy } \\
\text { women referred for antenatal } \\
\text { consultation because of fear of } \\
\text { vaginal delivery as diagnosed by } \\
\text { questionnaire. }\end{array}$ & $\begin{array}{l}\text { Contraindication } \\
\text { to vaginal } \\
\text { delivery at time } \\
\text { of } \\
\text { randomisation. }\end{array}$ & $\begin{array}{l}\text { Nulliparous and multiparous } \\
\text { women were separated for the } \\
\text { therapy groups. }\end{array}$ \\
\hline $\begin{array}{l}\text { Ryding et } \\
\text { al. }^{57}\end{array}$ & 2003 & $\begin{array}{l}\text { In } 1999,53 \text { Swedish speaking women } \\
\text { who consulted midwives in the FOC } \\
\text { team. } \\
30 \% \text { nulliparous }\end{array}$ & $\begin{array}{l}53 \text { women matched for parity and } \\
\text { mode of delivery as soon as } \\
\text { possible after delivery of study } \\
\text { group woman. }\end{array}$ & $\begin{array}{l}4 \text { women }-2 \text { in } \\
\text { another study, } 1 \\
\text { because of } \\
\text { psychiatric } \\
\text { illness, } 1 \text { child } \\
\text { custody } \\
\text { investigation. }\end{array}$ & \\
\hline
\end{tabular}

CS=caesarean section; FOC= Fear of childbirth 


\begin{tabular}{|c|c|c|c|c|c|}
\hline $\begin{array}{l}\text { Waldenström } \\
\text { et al. }{ }^{40}\end{array}$ & 2006 & $\begin{array}{l}290 \text { women who expressed very } \\
\text { negative feelings about birth in } 2^{\text {nd }} \\
\text { trimester and/or who received } \\
\text { counselling }\end{array}$ & $\begin{array}{l}\text { Reference group - } 2372 \text { women } \\
\text { who experienced no negative } \\
\text { feelings or counselling }\end{array}$ & $\begin{array}{l}\text { Women who } \\
\text { miscarried } \\
\text { Non-Swedish } \\
\text { speaking women }\end{array}$ & $\begin{array}{l}\text { A larger proportion of parous } \\
\text { women in two subgroups of } \\
\text { the intervention group had } \\
\text { had a previous emergency } \\
\text { CS. }\end{array}$ \\
\hline Sydsjö et al. ${ }^{59}$ & 2012 & $\begin{array}{l}353 \text { women who were referred to the } \\
\text { Unit for Psychosocial Obstetrics and } \\
\text { Gynaecology and who were diagnosed } \\
\text { as having a severe FOC. } \\
34.7 \% \text { nulliparous }\end{array}$ & $\begin{array}{l}579 \text { women who gave birth on } \\
\text { same day and who had not } \\
\text { received treatment at the Unit for } \\
\text { Psychosocial Obstetrics and } \\
\text { Gynaecology in the present } \\
\text { pregnancy } \\
41.8 \% \text { nulliparous }\end{array}$ & $\begin{array}{l}\text { Women who } \\
\text { gave birth at } \\
\text { other hospitals } \\
\text { and moved out } \\
\text { of the area. } \\
\text { Women with a } \\
\text { late miscarriage. }\end{array}$ & $\begin{array}{l}\text { Included in both groups are } \\
\text { women who had previously } \\
\text { had a CS. } \\
\text { Intervention group } 19.3 \% \text {, } \\
\text { reference group } 8.1 \%\end{array}$ \\
\hline
\end{tabular}

1. Nerum H, Halvorsen L, Sørlie Tand Øian P. maternal request for caesarean section due to fear of birth: can it be changed through crisis-oriented counseling? Birth 2006;33:221-228. 


\section{Appendix VIII - Descriptions of interventions for women with tokophobia}

\begin{tabular}{|c|c|c|c|c|}
\hline Author/s & Date & Overall description of intervention & Description of staff involved & Number of sessions \\
\hline $\begin{array}{l}\text { Sjögren and } \\
\text { Thomassen }^{15} \\
\text { Sjögren } \\
55\end{array}$ & 1998 & $\begin{array}{l}\text { Referral to a psychosomatic } \\
\text { outpatient clinic for individualised } \\
\text { psychological/obstetric support }\end{array}$ & $\begin{array}{l}\text { Psychosomatic specialist who was a } \\
\text { gynaecologist and psychotherapist }\end{array}$ & \\
\hline Saisto et al. ${ }^{21}$ & 2001 & $\begin{array}{l}\text { Intensive therapy. Provision of information; } \\
\text { conversation regarding previous obstetric } \\
\text { experiences, feelings and misconceptions; } \\
\text { appointments based on routine obstetric } \\
\text { check-ups combined with cognitive therapy; } \\
\text { appointment with midwife; visits to obstetric } \\
\text { ward. }\end{array}$ & $\begin{array}{l}\text { a) A trained obstetrician who was a qualified } \\
\text { therapist and who had completed a course in } \\
\text { childbirth psychology and cognitive therapy } \\
\text { b) A midwife }\end{array}$ & Number of visits not clear \\
\hline Ryding et al. ${ }^{57}$ & 2003 & $\begin{array}{l}\text { Counselling by midwives with opportunity for } \\
\text { referral to an obstetrician }\end{array}$ & $\begin{array}{l}\text { FOC team of eight midwives trained in } \\
\text { counselling and obstetrician who had } \\
\text { undergone basic training in psychotherapy }\end{array}$ & $\begin{array}{l}\text { Meetings occurred between } 1-14 \\
\text { times with a mean of } 4 \text { and once } \\
\text { (occasionally } 2 \text { or } 3 \text { times) after } \\
\text { the birth. }\end{array}$ \\
\hline Saisto et al..$^{58}$ & 2006 & $\begin{array}{l}\text { Group psychoeducation in conjunction with } \\
\text { relaxation exercises }\end{array}$ & $\begin{array}{l}\text { Psychologist and one session with a midwife } \\
\text { present }\end{array}$ & Five group sessions \\
\hline $\begin{array}{l}\text { Waldenström } \\
\text { et al. }{ }^{40}\end{array}$ & 2006 & $\begin{array}{l}\text { Referral to the Aurora clinics (specialist teams } \\
\text { to support women suffering from FOC). } \\
\text { Counselling }\end{array}$ & $\begin{array}{l}\text { Qualified teams of midwives supported by an } \\
\text { obstetrician, psychologist, social worker and } \\
\text { sometimes a psychiatrist. }\end{array}$ & $\begin{array}{l}\text { Visits varied but two to four were } \\
\text { common. }\end{array}$ \\
\hline Nerum et al. ${ }^{31}$ & 2006 & Crisis-oriented counselling & $\begin{array}{l}\text { The counselling team consisted of: } \\
\text { a) two experienced midwives, } \\
\text { b) a senior obstetric consultant } \\
\text { c) a social worker. } \\
\text { The team received additional training and } \\
\text { qualified guidance every two weeks. }\end{array}$ & $\begin{array}{l}\text { Women were offered individual } \\
\text { sessions in addition to the routine } \\
\text { antenatal appointments } \\
\text { The social worker gave advice } \\
\text { and information on rights under } \\
\text { the law }\end{array}$ \\
\hline $\begin{array}{l}\text { Halvorsen et } \\
\text { al. }^{56}\end{array}$ & 2010 & Crisis-oriented counselling & $\begin{array}{l}\text { Two midwives who had received training in } \\
\text { mental health with weekly qualified guidance. }\end{array}$ & $\begin{array}{l}\text { Meeting with midwife individually } \\
\text { Specific number of visits not } \\
\text { identified. }\end{array}$ \\
\hline Sydsjö et al. ${ }^{59}$ & 2012 & $\begin{array}{l}\text { Intensive therapy - Crisis-oriented counselling } \\
\text { and psycho-education }\end{array}$ & $\begin{array}{l}\text { a. Meetings with specially trained midwife } \\
\text { b. Consultation with an obstetrician } \\
\text { c. Consultation with a psychotherapist or } \\
\text { psychologist }\end{array}$ & One to ten sessions with each \\
\hline
\end{tabular}




\section{Appendix IX - Outcomes}

\begin{tabular}{|c|c|c|c|c|c|}
\hline Study & Date & Final choice for birthing & $\begin{array}{l}\text { Alterations in fear } \\
\text { and/or anxiety }\end{array}$ & Satisfaction with birth experience & Satisfaction with counselling \\
\hline $\begin{array}{l}\text { Sjögren and } \\
\text { Thomassen }^{15} \\
\text { Sjögren }^{55}\end{array}$ & $\begin{array}{l}1997 \\
1998\end{array}$ & $\begin{array}{l}\text { Of the } 68 \text { women in the study } \\
\text { group who initially requested } \\
\text { CS, after intervention } 38 \\
\text { agreed to vaginal delivery. }\end{array}$ & $\mathrm{N} / \mathrm{A}$ & $\begin{array}{l}\text { At } 1-3 \text { year follow-up, more women } \\
\text { in study group remembered birth as } \\
\text { easier than expected }(p=0.004) \text { and } \\
\text { felt in command of the delivery } \\
\text { ( } p=0.024) \text {. Other aspects } \\
\text { remembered no differently to } \\
\text { references. }\end{array}$ & $\begin{array}{l}\text { No significant differences in } \\
\text { satisfaction with medical, } \\
\text { emotional support and practical } \\
\text { support between the two groups. } \\
\text { More women in the study group } \\
\text { provided comments on how their } \\
\text { care could have been improved } \\
(\mathrm{p}=0.003) \text {. }\end{array}$ \\
\hline Saisto et al. ${ }^{21}$ & 2001 & $\begin{array}{l}62 \% \text { originally requesting CS } \\
\text { chose to deliver vaginally but } \\
\text { no difference between groups. }\end{array}$ & $\begin{array}{l}\text { After therapy, birth- } \\
\text { related concern } \\
\text { decreased in } \\
\text { intensive therapy } \\
\text { group; increased in } \\
\text { conventional therapy } \\
\text { group }(p=0.22) \text {. }\end{array}$ & $\begin{array}{l}\text { Women in intensive therapy group } \\
\text { remembered feeling less safe than } \\
\text { women in conventional therapy } \\
\text { group }(p=0.02) \text {. But no differences } \\
\text { in satisfaction with the birth. }\end{array}$ & $\mathrm{N} / \mathrm{A}$ \\
\hline Saisto et al. ${ }^{58}$ & 2006 & $\begin{array}{l}\text { Significantly more women in } \\
\text { the experimental group chose } \\
\text { to try vaginal delivery }(p=0.02)\end{array}$ & $\begin{array}{l}\text { Women in } \\
\text { experimental group } \\
\text { were twice as likely } \\
\text { to mention 'sharing } \\
\text { feelings' as a factor } \\
\text { in relieving fear than } \\
\text { 'receiving } \\
\text { information'. }\end{array}$ & $\mathrm{N} / \mathrm{A}$ & $\begin{array}{l}\text { Group session usefulness } 8.5 \pm \\
1.6 \text { (range } 3-10 \text { ) on a scale from } \\
1=\text { no benefit to } 10=\text { maximal } \\
\text { benefit. } \\
\text { Usefulness of relaxation exercises } \\
\text { was rated } 6.9 \pm 1.8 \text { (range } 3-10 \text { ). }\end{array}$ \\
\hline
\end{tabular}




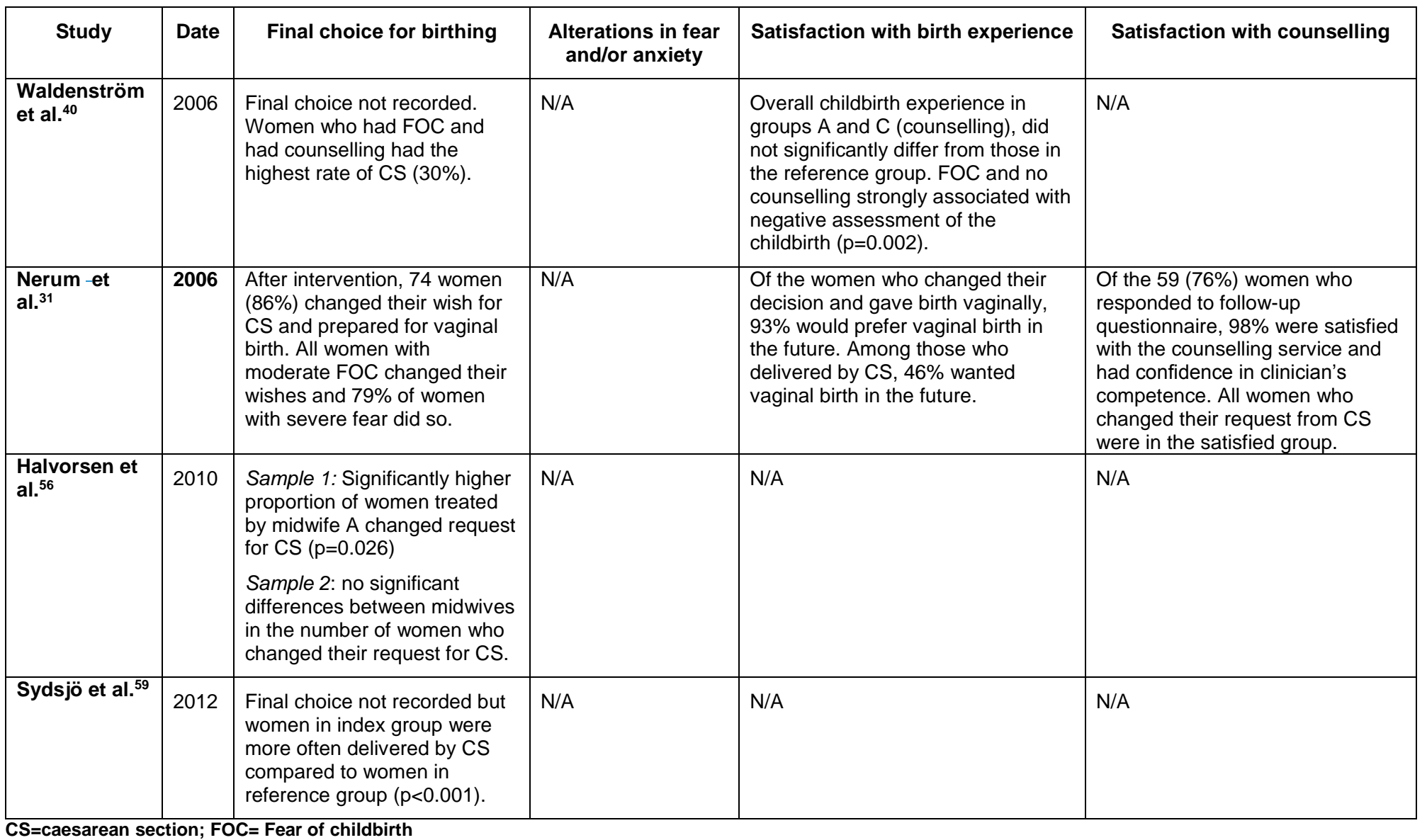

